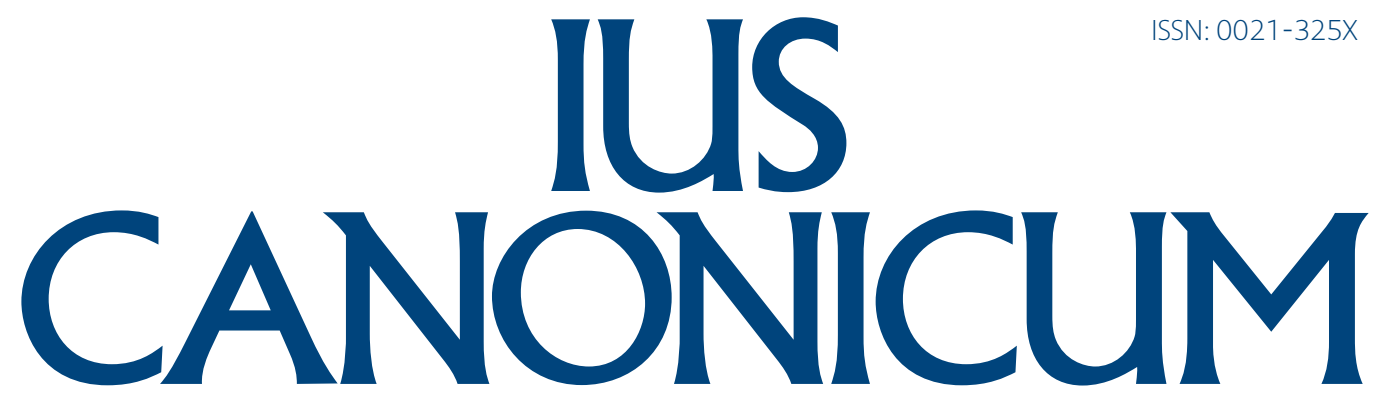

REVISTA DEL INSTITUTO MARTÍN DE AZPILCUETA

FACULTAD DE DERECHO CANÓNICO

UNIVERSIDAD DE NAVARRA

VOLUMEN 57
NÚMERO 113

JUNIO 2017 


\section{IUS CANONICUM}

REVISTA SEMESTRAL DEL INSTITUTO MARTÍN DE AZPILCUETA / FACULTAD DE DERECHO CANÓNICO

DE LA UNIVERSIDAD DE NAVARRA / PAMPLONA. ESPAÑA / FUNDADA EN 1961 / ISSN: 0021-325X

JUNIO 2017 / VOLUMEN 57

DIRECTOR / EDITOR

Jorge Otaduy

UNIVERSIDAD DE NAVARRA

jorotaduy@unav.es

CONSEJO EDITORIAL

EDITORIAL BOARD

VOCALES

Daniel Cenalmor UNIVERSIDAD DE NAVARRA

Alejandro González-Varas UNIVERSIDAD DE ZARAGOZA

Julián Ros Córcoles

VICARIO JUDICIAL. ALBACETE

Joaquín Sedano

UNIVERSIDAD DE NAVARRA

Ana $M^{\text {a }}$ Vega Gutiérrez

SECRETARIO

Eduardo Flandes

UNIVERSIDAD DE NAVARRA

eflandes@unav.es

CONSEJO ASESOR / ADVISORY BOARD

\author{
Nicolás Álvarez \\ de las Asturias \\ UNIVERSIDAD ECLESIÁSTICA \\ SAN DÁMASO, \\ MADRID (ESPAÑA)
}

\section{Juan Ignacio Arrieta \\ PONTIFICIO CONSIGLIO PER I TESTI \\ LEGISLATIVI, ROMA (CIUDAD DEL \\ VATICANO)}

Orazio Condorelli

UNIVERSITÀ DEGLI STUDI DI

CATANIA (ITALIA)

Myriam Cortés

UNIVERSIDAD PONTIFICIA

DE SALAMANCA (ESPAÑA)

\section{Brian Ferme \\ CONSIGLIO PER L'ECONOMIA, ROMA (CIUDAD DEL VATICANO)}

Ombretta Fumagalli Carulli UNIVERSITÀ CATTOLICA DEL SACRO CUORE, MILANO (ITALIA)
Alberto de la Hera
UNIVERSIDAD COMPLUTENSE
DE MADRID (ESPAÑA)

\section{Luis Navarro \\ UNIVERSITÀ PONTIFICIA DELLA \\ SANTA CROCE, ROMA (ITALIA) \\ Rafael Navarro-Valls \\ UNIVERSIDAD COMPLUTENSE \\ DE MADRID (ESPAÑA)}

María Elena Olmos
UNIVERSIDAD DE VALENCIA (ESPAÑA)

Carmen Peña

UNIVERSIDAD PONTIFICIA COMILLAS, MADRID (ESPAÑA)

Helmut Pree

LUDWIG-MAXIMILIANS-UNIVERSITÄT, MÜNCHEN (ALEMANIA)

\section{María José Roca UNIVERSIDAD COMPLUTENSE DE MADRID (ESPAÑA)}

Antoni Stankiewicz

TRIBUNALE DELLA ROTA ROMANA, ROMA (ITALIA)

José María Vázquez

García-Peñuela

UNIVERSIDAD INTERNACIONAL

DE LA RIOJA (ESPAÑA)

Ius Canonicum es una revista general de Derecho canónico y de Derecho eclesiástico. Publica artículos científicos sometidos a revisión por expertos relativos a todos los sectores del ordenamiento canónico así como también los textos legislativos promulgados por la Santa Sede, la actividad del CPTL, y sentencias de los Tribunales de la Santa Sede, oportunamente comentados. Completan cada volumen la sección de recensiones y de crónicas de jurisprudencia, de legislación y de reuniones científicas.

Ius Canonicum is a journal of canon law and ecclesiastical law which publishes peer-reviewed articles written by experts on all matters relating to canon law and the legislative texts issued by the Holy See, the actions of the CPTL, and the sentences handed down by the tribunals of the Holy See, annotated as appropriate. The final section of each edition comprises a set of reviews and reports on jurisprudence, legislation and academic congresses. 


\begin{tabular}{ll}
\hline Redacción y & Precios 2017 \\
Administración & Unión Europea \\
Instituto «Martín & 1 año, 2 fascículos / 57 € \\
de Azpilcueta» & Número atrasado / 32 € \\
Universidad de Navarra & Otros países \\
31009 Pamplona & 1 año, 2 fascículos / 96 € \\
(España) & Número atrasado / $50 €$ \\
T948425600 & \\
F948425633 & Sólo versión \\
spublicaciones@unav.es & electrónica / 40 € \\
mww.unav.es/ima & Fotocomposición \\
Suscripciones & NovaText \\
spublicaciones@unav.es & Imprime \\
Edita & GraphyCems \\
Servicio de Publicaciones & D.L. NA 197-1961 \\
de la Universidad de & Periodicidad \\
Navarra & Semestral \\
& Junio y diciembre
\end{tabular}

Tamaño $170 \times 240$ mm
Ius Canonicum figura en los siguientes índices y bases de datos:

- SCOPUS.

- ERIH Plus (European Reference Index for the Humanistics and Social Sciences).

- CNKI (China National Knowledge Infrastructure).

- ACADEMIC SEARCH COMPLETE (EBSCO).

- FRANCIS (Institute d'Information Scientifique, Centre National de la Recherche Scientifique, FR).

- PERIODICAL INDEX ONLINE (Pro-Quest, GB).

- ISOC, CIENCIAS SOCIALES Y HUMANIDADES (Centro de Ciencias Humanas y Sociales del CSIC, ES).

- CANON LAW ABSTRACTS (Canon Law Society of Great Britain and Ireland).

- RELIGIOUS AND THEOLOGICAL ABSTRACTS (William Sailer, USA).

- DIALNET (Universidad de La Rioja, ES).

Ius Canonicum figura en los siguientes rankings y clasificaciones de revistas:

- RESH (Sistema de valoración integrada de revistas españolas de Humanidades y Ciencias Sociales).

- CIRC (Clasificación integrada de revistas científicas).

- CARHUS Plus Agència de Gestió d'Adjuts Universitaris y de Rècerca.

- IN-RECJ (Índice de impacto de las revistas españolas de ciencias jurídicas).

- DICE (Difusión y Calidad Editorial de las Revistas Españolas de Humanidades y Ciencias Sociales y Jurídicas).

- Directorio y Catálogo LATINDEX (Sistema regional de información en línea para revistas científicas de América Latina, el Caribe, España y Portugal).

El contenido de la revista es accesible en formato electrónico en Dadun, repositorio de la Universidad de Navarra (http://dadun.unav.edu), con un periodo de embargo para los números más recientes.

Las opiniones expuestas en los trabajos publicados por la revista son de la exclusiva responsabilidad de sus autores. 


\section{IUS CANONICUM}

JUNIO 2017 / VOLUMEN 57

\section{ESTUDIOS / ARTICLES}

\section{ESTUDIOS SOBRE EL MOTU PROPRIO MITIS IUDEX(II)}

Gerardo NúÑEZ

La fase preliminar del nuevo proceso de nulidad

$9-44$

The Preliminary Phase of the New Nullity Proceedings

Juan Ignacio BAÑARES

El artículo 14 de las Reglas de Procedimiento del M. P. Mitis Iudex.

Supuestos de hecho y causas de nulidad

On Article 14 of the Rules of Procedure of Motu Proprio Mitis ludex:

Facts and Grounds of Marriage Nullity

Paolo BIANCHI

Il servizio alla verità nel processo matrimoniale

Serving the Truth in the Marriage Process

Montserrat GAS-AIXENDRI

La dimensión jurídica del matrimonio canónico a la luz del magisterio reciente. Observaciones a propósito de la reforma del proceso

de nulidad realizado por el Motu proprio Mitis Iudex

$105^{-128}$

The Juridical Dimension of Canonical Marriage according to Recent Magisterium:

Comments on the Recent Reform of the Nullity Process in Motu Proprio Mitix ludex

Carlos José ERrázURIZ

La indisolubilidad del matrimonio: su problemática comprensión actual y la importancia de una fundamentación antropológico-jurídica

The Indissolubility of Marriage: Its Problematic Current Understanding

and the Importance of an Anthropological-Juridical Foundation 


\section{OTROS ESTUDIOS}

Javier OTADUY

Dulcor Misericordiae. Justicia y misericordia en el ejercicio de la autoridad canónica. II. El capítulo octavo de Amoris Laetitia

Dulcor Misericordiae. Justice and Mercy in the Exercise of Canonical Authority.

$153^{-201}$

II. Chapter 8 of Amoris Laetitia

José María Chiclana

Los fieles miembros de ordinariatos para antiguos anglicanos

y su incorporación a la diócesis

The Faithful of Ordinariates for Former Anglicans and their Incorporation into

the Diocese

José María MARTí SÁNCHEZ

El abogado ante las causas matrimoniales canónicas.

Ciertas cuestiones deontológicas

The Lawyer in Canonical Marriage Causes. Some Ethical Issues

Christina HIP-FLORES

Estudio canónico sobre la viudez consagrada

Canonical Study of Consecrated Widowhood

GUÍAS CANÓNICAS / CANONICAL GUIDES

Jorge MiRAs

Guía para el procedimiento administrativo canónico

en materia penal

Practical Guide to Canonical Administrative Procedure in Penal Matters

CRÓNICAS / NEWS DIGEST

Joaquín SEDANO

Crónica de Derecho canónico 2016

389-406

Jorge OTADUY

Crónica de Legislación 2016. Derecho eclesiástico español

$407-415$

Jorge OTADUY

Crónica de Jurisprudencia 2016. Derecho eclesiástico español

$417-446$ 


\section{BIBLIOGRAFÍA / BOOK REVIEWS}

\section{RECENSIONES}

Aimone Braida, P. V., Le Finanze del Papa (M. Á. López LozAno)

$449-452$

Bañales LeOz, J. Ma , La lengua latina del Código de Derecho Canónico

(estudio sintáctico) (J. Bosch CarReRA)

$453-454$

Bueno Salinas, S., Las personas jurídicas en el Derecho canónico (J. OtAduY)

$454-457$

DE Boccard, N., Charisme et Instituts de vie consacrée. Les canons 578 et 587 du Code de droit canonique de 1983 (préface du cardinal Philippe Barbarin)

(D. Le TOURNEAU)

$457^{-460}$

Dounot, C. - Dussaubat, F. (dirs.), La reforme des nullités de mariage.

Une étude critique (J. A. FUENTES)

FERnÁNDEZ SAN Román, J., La admisión al matrimonio de los que notoriamente abandonaron la fe y de los censurados. Estudio histórico-canónico del iter redaccional de los cánones 1065 y 1066 en la codificación de 1917 y de las demás fuentes hasta el Concilio Vaticano I/ (Ma J. RocA)

GONZÁlez AYESTA, J. (ed.), Eficacia en el derecho estatal de normas o actos de las confesiones religiosas (J. OTADUY)

Hünermund, T., Kirchensteuer und Kapitalertragsteuer. Die Auswirkungen des Unternehmensteuerreformgesetzes 2008 im System der Kirchensteuererhebung $\left(M^{\mathrm{a}} \mathrm{J}\right.$. RocA)

Meens, R., Penance in Medieval Europe. 600-1200 (J. Sedano)

Palomino, R., La religión en el espacio público. Los símbolos religiosos ante el Derecho (Á. LÓPEZ-SIDRO LÓPEZ)

Quintana Bescós, R. - Royo Mejía, A., Proceso diocesano en las Causas de los Santos (J. C. Martín DE LA Hoz)

VINCES ARbulú, M., El sistema matrimonial peruano: evolución y perspectivas de futuro (J. MANTECÓN) 


\title{
Guía para el procedimiento administrativo canónico en materia penal
}

\author{
Practical Guide to Canonical Administrative Procedure \\ in Penal Matters
}

Jorge MIRAS

Profesor Ordinario de Derecho Administrativo Canónico Universidad de Navarra. Facultad de Derecho Canónico orcid 0000-0001-7194-7961

jmiras@unav.es

Resumen: La guía tiene una primera parte que presenta sintéticamente algunos conceptos y elementos básicos del sistema penal canónico; y una segunda en la que se ilustra un posible itinerario para proceder administrativamente en materia penal. Se añade un anexo que contiene esquemas básicos de algunos posibles decretos singulares previos al procedimiento penal.

Palabras clave: Pena, Derecho penal, Procedimiento administrativo, Guía práctica, Delito, Investigación.
Abstract: The first part of this guide summarizes some basic concepts and elements of penal canon law. The second illustrates one possible way of proceeding administratively in penal matters. The appendix offers an outline of some possible singular decrees, prior to the procedure of imposing a penalty.

Keywords: Penalty, Penal Canon Law, Administrative Procedure, Practical Guide, Delict, Investigation.

Sumario: I. SínTesis De algunos fundamentos. 1. El sistema penal canónico en el gobierno pastoral: criterios generales. 2. El delito, presupuesto necesario de la pena. 3. Tipos de penas previstas en el CIC. 4. Principales delitos tipificados en Derecho canónico. II. Procedimiento. 5. La noticia de un posible delito, comienzo de las actuaciones. 6. La investigación previa. 7. Modo de proceder para la imposición o para la declaración de penas. 8. Normas y criterios sobre la fijación de la pena. Breve bibliografía complementaria. Anexo: Esquema básico de algunos decretos previos al procedimiento penal. 


\section{SÍNTESIS DE ALGUNOS FUNDAMENTOS}

\section{El SISTEMA PENAL CANÓNICO EN EL GOBIERNO PASTORAL:}

\section{CRITERIOS GENERALES}

1.1. Función de gobierno pastoral y penas canónicas. La función de gobierno de los Pastores sagrados incluye la potestad de imponer sanciones proporcionadas para proteger valores eclesiales relevantes, cuando lo exige el bien común de la Iglesia. El c. $1311 \$ 1$, recogiendo una afirmación presente ya en el CIC anterior y en toda la tradición canónica, proclama: «La Iglesia tiene derecho originario y propio a castigar con sanciones penales a los fieles que cometen delitos».

Los calificativos «originario»y «propio» indican aquí, entre otras cosas, que no se trata de un derecho recibido de otra autoridad humana, ni tampoco de una imitación de sistemas jurídicos ajenos a la Iglesia. Por el contrario, las finalidades que legitiman la existencia de un sistema penal proporcionado en toda sociedad (cfr. CCE, 2266), se descubren como pertinentes también en la Iglesia, si se piensa en la responsabilidad que incumbe a los sagrados Pastores.

Estos tienen el deber de velar por la integridad de la comunión en la fe, en el culto y en el régimen -elementos esenciales del bien común eclesial: es decir, del conjunto de condiciones necesarias para que sea posible alcanzar el fin de la Iglesia-, así como por otros valores de especial trascendencia humana y cristiana, protegiéndolos incluso coactivamente, cuando es necesario. Lógicamente, las manifestaciones concretas de esta dimensión de la función pastoral de gobierno deben reflejar siempre la naturaleza propia de la Iglesia.

1.2. Potestad y deber de los Pastores sagrados. La potestad coactiva, por su propia naturaleza, entraña al mismo tiempo un deber. Su ejercicio no responde, naturalmente, a un reprobable afán de venganza; ni implica falta de comprensión y misericordia, ni presupone la actitud orgullosa y distante de quien se considera incapaz de caer. Al contrario, se ha de llevar a cabo con humildad y mansedumbre, con solicitud paternal lejana de toda arrogancia, con discernimiento prudente y con agudo sentido de responsabilidad.

En cuanto a este último aspecto, no se puede olvidar que no se trata de una facultad jurídica de libre disposición, destinada simplemente a am- 
pliar la esfera jurídica personal de su titular (como sucedería con ciertos privilegios, que podrían ejercerse o no: cfr., p. e., c. $80 \$ 2$ ), sino de una potestad pública irrenunciable, perteneciente al oficio pastoral, que se recibe con todo el conjunto de atribuciones propias de este como instrumento necesario -junto a los demás recursos de la caridad pastoral- para cumplir eficaz y responsablemente la misión de gobierno, cuando se dan ciertas circunstancias.

En toda actuación penal, se debe buscar siempre primariamente restituir la justicia, es decir, atender a las heridas espirituales y materiales causadas por el delito, erradicando o neutralizando su causa y reparándolas, en la medida en que ello esté al alcance de las facultades jurídicas del Pastor (sin duda, pueden y deben usarse simultánea o sucesivamente otros medios, que acompañan y complementan, pero no pueden sustituir -salvo en los casos expresamente previstos por el Legislador- a la actuación penal, cuando esta sea la respuesta requerida). $\mathrm{Al}$ mismo tiempo, ha de procurarse en lo posible la enmienda del culpable, su salvación. Por último, se debe procurar también la reparación del escándalo -especialmente, aunque no solo entre los fieles-, evitando que se difundan dudas, ambigüedades o confusiones acerca de la actitud de la Iglesia ante determinadas conductas que falsean su verdad y hieren su rostro.

Por estas razones, «en la imagen de una Iglesia que tutela los derechos de cada fiel, y que -más aún- promueve y protege el bien común como condición indispensable para el desarrollo integral de la persona humana y cristiana, se inserta positivamente la disciplina penal: también la pena impuesta por la autoridad eclesiástica (...) debe ser considerada como un instrumento de comunión, esto es, como un medio de recuperar aquellas deficiencias del bien individual y del bien común que han surgido con el comportamiento antieclesial, delictivo y escandaloso de los miembros del pueblo de Dios» (Juan Pablo II, Discurso a la Rota Romana, 1979).

1.3. La actuación penal en el contexto de la actividad pastoral. El c. 1341 establece que el Ordinario debe iniciar el procedimiento para imponer una pena «solo cuando haya visto que la corrección fraterna, la reprensión u otros medios de la solicitud pastoral no bastan» para conseguir las finalidades mencionadas. La imposición de sanciones se considera, así, un recurso de la solicitud pastoral para situaciones especialmente graves. Efectivamente, el carácter de ultima ratio, de recurso extremo que se atribuye al derecho penal en todo or- 
denamiento asume en el canónico una intensidad específica, derivada de su carácter pastoral.

No obstante, «es oportuno detenerse a reflexionar sobre un equívoco, tal vez comprensible, pero no por eso menos dañoso, que lamentablemente condiciona con frecuencia la visión de la pastoralidad del Derecho eclesial. Esa distorsión consiste en atribuir alcance e intenciones pastorales únicamente a aquellos aspectos de moderación y humanidad que se pueden relacionar directamente con la aequitas canónica, es decir, consiste en sostener que solo las excepciones a las leyes, el evitar el recurso a los procesos y a las sanciones canónicas, y el reducir las formalidades jurídicas, tienen de verdad importancia pastoral. Se olvida de este modo que también la justicia y el estricto derecho $-\mathrm{y}$, por consiguiente, las normas generales, los procesos, las sanciones y las demás manifestaciones típicas de la juridicidad, siempre que resulten necesarias- son exigidas en la Iglesia para el bien de las almas y son, por lo tanto, realidades intrínsecamente pastorales» (Juan Pablo II, Discurso a la Rota Romana, 1990).

Efectivamente, cuando se dan situaciones que requieren por su naturaleza una actuación penal, es manifestación del compromiso del Buen Pastor llevarla a cabo con diligente prudencia, templada fortaleza y justicia vivificada por la caridad hacia Dios, hacia su Iglesia, hacia la grey encomendada y hacia el propio protagonista de la conducta quizá delictiva. La omisión de ese deber podría constituir incluso un delito específico (cfr. c. 1389).

Se trata, no obstante, de un campo de la responsabilidad pastoral extremadamente delicado, tanto por los efectos de las medidas que se adoptan sobre personas determinadas, como por su trascendencia y su eventual resonancia pública. Esto, unido al temor a errar, por falta de la necesaria familiaridad con los elementos técnicos del derecho penal canónico para actuar de manera adecuada, puede fomentar en no pocos casos una inseguridad que lleve a evitar recurrir a las medidas de carácter penal, aun en situaciones en las que los «otros medios de la solicitud pastoral» que menciona el c. 1341 constituirían claramente una reacción insuficiente e inadecuada para atajar y sanar el daño causado a los fieles -sin excluir al propio delincuente- y a la Iglesia.

La observancia de las disposiciones canónicas en esta materia garantiza en buena medida, a cuantos han recibido esa responsabilidad, que su actuación sea recta, eficaz, proporcionada, respetuosa de la dignidad de los fieles y atenta al valor de los bienes eclesiales que debe tutelar. Esta breve guía pretende 
facilitar la interpretación y aplicación del derecho penal en los supuestos que lo requieran. Para ello ofrece una síntesis de los conceptos y normas principales, y procura sugerir modos adecuados de proceder para tutelar, en la medida de lo posible, todos los bienes en juego.

\section{El DELITO, PRESUPUESTO NECESARIO DE LA PENA}

2.1. Distinción entre pecado y delito. No toda infracción moral (pecado) o jurídica es propiamente delito. Solo determinadas conductas externas con especial incidencia negativa en la vida de la Iglesia y de los fieles son calificadas en derecho como delito y castigadas proporcionalmente, atendiendo a las finalidades señaladas (vide 1.1 y 1.2 ).

- Para que exista un delito se requiere:

- Que se haya cometido una violación externa de una ley o de un precepto (c. $1321 \$ 1)$.

- Que esa infracción externa sea gravemente imputable a su autor o a sus autores (ibid.).

- Que la infracción cometida esté tipificada como delito y castigada con una pena por una norma jurídica (cfr. c. $1321 \$ 2$ ).

2.2. Violación externa de una ley o de un precepto (cfr. cc. 1315 y 1319; vide 2.4). Se entiende que una infracción es externa cuando no consiste solo en actos internos (pensamientos, proyectos, deseos, etc.), que no tienen relevancia jurídica, aunque puedan ser moralmente reprochables.

- La infracción externa puede ser consumada o no consumada:

- Cuando, con intención de delinquir, se han realizado actos que por su misma naturaleza se orientan a conseguir el resultado delictivo, pero no se llega a consumar el delito por causas ajenas a la voluntad del sujeto, se trata de un delito frustrado (cfr. c. $1328 \$ 1$ ).

- Si la no consumación se debe a que el sujeto no empleó los medios idóneos para conseguir el resultado delictivo propuesto, o a que desistió voluntariamente antes de alcanzar ese resultado, se tratará de una tentativa de delito (cfr. c. 1328 \$2).

- En general, el derecho canónico castiga solo el delito consumado. Tanto el delito frustrado como la tentativa pueden castigarse con penas inferiores a la prevista para el delito consumado, o con una penitencia o un remedio penal en su lugar (cfr. cc. 1328; 1339-1340; vide 3.3). 
2.3. Imputabilidad grave. Que existe «imputabilidad», en sentido jurídico, significa que la responsabilidad de una conducta delictiva es atribuible formalmente (es decir, en cuanto delito, no solo en cuanto conducta material) a su autor (y a los coautores y cómplices, según lo dispuesto en el c. 1329).

2.3.1. Deliberación y voluntariedad. Para que una conducta delictiva imputable resulte, además, punible, es necesario, según el c. $1321 \S 1$, que la imputabilidad sea grave. Por tanto, solo puede castigarse si, en la medida en que es posible determinarlo externamente, queda establecido que el sujeto ha actuado con deliberación y voluntariedad suficientes para que la imputabilidad pueda calificarse de grave (en la práctica, con criterios análogos a los usados por la ciencia moral respecto al pecado).

- No delinquen (no son capaces de ello) quienes carecen habitualmente de uso de razón, aunque hayan infringido una norma penal cuando parecían estar sanos (cfr. c. 1322).

2.3.2. Dolo y culpa. Una infracción puede ser imputable por dolo, que en el ámbito penal significa intención deliberada de infringir la norma de que se trate (no necesariamente engaño, como en otros ámbitos del derecho); o por cul$p a$, es decir, por omisión de la diligencia debida (cfr. c. $1321 \$ 1$ ).

- La pena prevista por el derecho para un delito solo se aplica en caso de que la conducta haya sido dolosa. En cambio, si la infracción es culposa debe ser castigada con una pena inferior a la prevista (cfr. c. $1321 \$ 2$ ).

2.3.3. Circunstancias que modifican la imputabilidad. El CIC regula una serie de circunstancias que modifican la imputabilidad: eximentes, que hacen que no se incurra en pena alguna (cc. 1323 y 1325); atenuantes, que permiten imponer penas menores o sustituirlas por una penitencia (cc. 1324-1325); y agravantes, que permiten aumentar la pena (c. 1326).

- Además, la ley particular puede establecer otras circunstancias eximentes, atenuantes o agravantes. Lo mismo puede hacer el precepto penal (vide 2.4), pero solo para el supuesto concreto al que se refiere (cfr. c. 1327). Estas circunstancias deben valorarse en el momento de imponer la pena (normalmente no antes, para que quede constancia de que se ha procedido conforme a derecho: vide 2.3.6; 8.3). 
2.3.4. Atenuantes y penas «latae sententiae». Las penas latae sententiae (vide 3.1.1), cuando se dan los requisitos previstos por el derecho, recaen ipso facto sobre quien comete el delito, sin necesidad de procedimiento alguno para su imposición. Sin embargo, el delincuente no incurre en ellas, no solo cuando se da una circunstancia eximente -como ocurre en las demás penas-, sino tampoco cuando se da una simple atenuante (cfr. c. $1324 \$ 3$ ).

2.3.5. Supuestos de ignorancia que no excusan. El c. 1325 prevé explícitamente que nunca son eximentes ni atenuantes, entre otros, los supuestos de ignorancia crasa, supina y afectada: los tres tipos tradicionales de ignorancia vencible, que sin embargo el sujeto no vence por negligencia, por desinterés o por malicia (la ignorancia maliciosa es positivamente querida porque, en caso de vencerla, el sujeto podría llegar a conocer exactamente obligaciones o prohibiciones que no quiere cumplir y prefiere ignorar).

2.3.6. Momento en que se deben valorar las eximentes y atenuantes. En general -salvo supuestos evidentes que excluyan toda imputabilidad-, es preferible que estas circunstancias se valoren en el seno del correspondiente proceso o procedimiento penal (vide 7 y 8), si se decide iniciarlo (cfr. c. 1718), no antes, de modo que la absolución o la condena se realicen con las necesarias garantías.

- Durante la investigación previa (vide 6) es suficiente determinar si el hecho resulta, en principio, imputable; o, dicho de otro modo (más preciso en la práctica), si no resulta claramente no imputable. En efecto, ha de tenerse en cuenta que, si se ha cometido la infracción externa, el derecho presume (salvo prueba en contrario) que es imputable (cfr. c. $1321 \$ 3$ ) lo cual permitiría proceder penalmente. Sin embargo, esa presunción de imputabilidad no implica una correlativa presunción del dolo (vide 2.3.2), que deberá probarse en todo caso dentro del proceso o procedimiento correspondiente.

2.3.7. Cooperación de varios sujetos en el mismo delito. Es posible que, además del autor principal, otras personas participen de diversas formas y en distintos grados en la comisión de un delito. Su implicación y las consecuencias penales subsiguientes deberán quedar probadas como resultado de las mismas actuaciones que se siguen para establecer la situación penal del autor principal de un posible delito (vide 6-8). 
- Aunque se trata de una distinción doctrinal, que el CIC no necesariamente utiliza de modo estricto, suele hablarse de coautores, si están de acuerdo y realizan de manera conjunta la misma acción delictiva; o de cómplices, en otras formas de cooperación, como mandar, inducir o instigar la comisión del delito, hacerla posible (si el delito no se hubiera podido cometer sin esa cooperación necesaria), simplemente facilitarla (cooperación accesoria), ocultarla, etc.

- El principio que se recoge a este respecto en el CIC es que todos los que cooperan a la comisión del delito con la misma intención de delinquir (aunque no sea por los mismos motivos) son también imputables, o sea, responsables del mismo delito. Estarán sujetos, en consecuencia, a las penas previstas para ellos por la ley o por el precepto penal infringidos, si los menciona expresamente; y si solo mencionan expresamente al autor principal, a las mismas penas previstas para él, o a otras inferiores, según el tipo y grado de su participación (cfr. c. 1329 $\$ 1)$.

- Cuando se trata de penas latae sententiae (vide 3.1.1), los coautores y cooperadores necesarios, si no pueden recibir la misma pena que el autor principal (p. e., porque son laicos y la pena prevista solo afecta a los clérigos), pueden ser castigados con otras penas ferendae sententiae (cfr. c. 1329 \$2).

2.4. Tipificación: la ley penal y el precepto penal. Propiamente, solo se puede hablar de delito cuando la infracción cometida está tipificada como tal y es castigada con una pena por una norma jurídica (cfr. c. $1321 \$ 2$ ), que puede ser una ley penal, universal o particular (c. 1315), o un precepto penal (c. 1319).

2.4.1. La ley penal. Conforme al c. $1315 \$ 1$, quien tiene potestad legislativa puede dar leyes penales, es decir, leyes que establecen una pena para una conducta que pasa a ser delictiva -al ser objeto de tipificación jurídica como delito- a partir de ese momento.

- Poseen esta potestad de dar leyes penales en el ámbito de su competencia: el Romano Pontífice y el Concilio Ecuménico con su Cabeza; el Obispo diocesano y sus equiparados o asimilados en derecho; el Concilio particular; y quien haya recibido del Legislador supremo una delegación de la potestad legislativa (cfr. c. $135 \$ 2$ ). 
- Tanto la ley universal como la particular (cfr. cc. 7-22) pueden establecer la conducta delictiva ex novo; y también proteger con una pena lo que está ya mandado o prohibido por el derecho divino.

- La ley penal particular (cfr. c. $1315 \$ 3$ ) puede, además, en el ámbito de su competencia (siempre teniendo en cuenta los criterios de los cc. 1316-1318):

- Reforzar con una pena el mandato o la prohibición establecidos por una ley universal.

- Añadir penas a las ya establecidas para un delito tipificado por la ley universal (aunque no debe hacerlo sin gravísima necesidad).

- Determinar o establecer como obligatoria una pena que el derecho universal ha dejado indeterminada (cfr. $1315 \$ 2$ ) o ha establecido como facultativa (vide 3.1.2).

- No puede, sin embargo, establecer la pena de expulsión del estado clerical, que se reserva a los supuestos determinados por el Legislador universal (c. 1317).

2.4.2. El precepto penal. A diferencia de la ley penal, que procede de la potestad legislativa, el precepto penal procede de la potestad ejecutiva (también en los casos en que la autoridad que lo da es, además, legislador: p. e., el Obispo diocesano).

- El c. 1319, con una expresión indirecta, atribuye la competencia para dar un precepto penal a quien puede dar preceptos en el fuero externo, en virtud de su potestad de jurisdicción: es decir, a aquella autoridad ejecutiva que, según derecho, tenga potestad y competencia para imponer a una persona o a unas personas determinadas, para un caso particular, la obligación de hacer u omitir algo, mandado o no por una ley anterior (cfr. c. 49). Ese precepto será penal si, al mismo tiempo que impone o urge la obligación de que se trate, conmina (es decir, amenaza) con una pena, siempre determinada (vide 3.1.2), para el caso de incumplimiento.

2.4.2.1. Distinción entre precepto penal y decreto penal. En el sistema de derecho canónico vigente, en la práctica, el precepto penal será siempre singular (cfr., especialmente, cc. 35-39; 48-58). Sin embargo, debe evitarse confundirlo con el llamado decreto penal, ya que se trata de dos actos que se refieren a fases distintas y no intercambiables de la actuación penal. 
- En efecto, el decreto penal (cfr. cc. 1342, 1353) es el decreto extrajudicial por el que se impone una pena, como conclusión del procedimiento indicado en el c. 1720 (vía administrativa para la imposición de penas: vide 7). Se trata también, como en el caso del precepto penal, de un decreto administrativo singular (dado en virtud de la potestad ejecutiva); pero si el precepto penal tiene, puede decirse, una función análoga a la de la ley penal, la función del decreto penal es análoga a la de la sentencia penal.

- Así, el precepto penal establece o prevé (constituye) la pena (como medio de reforzar el mandato que impone); y el decreto penal la impone o la declara (una vez resulta probado que se ha infringido una ley o el propio precepto penal que ha establecido la pena).

\subsubsection{Ejemplo de los diversos momentos de la actuación de la autoridad.} Si un fiel está teniendo un comportamiento que daña la vida de la Iglesia, o incumpliendo una obligación ya impuesta por el derecho, la autoridad competente, después de sopesar la cuestión (cfr. cc. $1319 \$ 2$ y 1317), puede exigirle mediante precepto que haga o deje de hacer algo en un plazo determinado, advirtiéndole que, en caso de no hacerlo, incurrirá en la pena que se establece en el mismo precepto (y que no estaba prevista antes ya con carácter general por el derecho, si lo estuviera, el precepto no sería propiamente penal: el delito y la pena correspondiente no serían establecidos por el precepto, sino por la ley penal previa, que el precepto se limitaría a urgir).

- Si transcurre el plazo indicado sin cumplimiento, el reo comete el delito establecido por el precepto y queda sujeto a la pena conminada.

- La autoridad ha de proceder correctamente para imponer esa pena, que generalmente no es «automática» (es decir, no queda impuesta ya por el mero hecho de desobedecer el precepto). Normalmente, se deberá seguir el procedimiento previsto para la imposición de penas por vía administrativa (cfr. c. 1720; vide 7), abreviando u omitiendo todas aquellas diligencias que pudieran ser innecesariamente redundantes, según la naturaleza del caso y teniendo en cuenta los trámites jurídicos ya realizados. En todo caso, se deberá garantizar cuidadosamente el derecho de defensa del reo. El procedimiento concluirá con 
un nuevo decreto emitido conforme al c. $1720 \$ 2$, que es el que impone la pena.

- El reo solo incurriría en la pena «automáticamente», haciendo así innecesario el procedimiento para su imposición, cuando el precepto penal hubiera previsto una pena latae sententiae (vide 3.1.1), cosa que no debe hacer, a no ser que se trate de delitos dolosos (vide 2.3.2) especialmente escandalosos y difíciles (cfr. cc. $1319 \$ 2$ y 1318). Si fuera este el caso, la doctrina estimaba, ya en la época del CIC de 1917, que el propio precepto equivaldría a la amonestación previa que es necesaria para imponer válidamente una censura (cfr. c. 1347), por lo que el reo conminado legítimamente con una censura latae sententiae mediante precepto, quedaría sujeto a la pena desde el mismo momento en que se produjera el incumplimiento (vide $3.1 ; 3.2$ ).

2.4.2.3. Alcance y limitaciones jurídicas del precepto penal. Según el derecho vigente, por precepto penal:

- No se puede imponer o aplicar ninguna pena por hechos pasados, solo conminar, con ella, es decir, establecer en un caso singular que a determinada infracción futura le corresponderá una pena.

- No se pueden realizar las funciones normativas, de carácter general y abstracto, que el c. $1315 \$ 3$ permite a la ley penal particular.

- No se puede establecer la pena de expulsión del estado clerical, que el c. 1317 reserva a la ley universal (vide 3.2.2.4).

- No se pueden establecer penas expiatorias perpetuas (cc. $1319 \$ 1$; $1314 \$ 1,2^{\circ}$; vide 3.2).

- No se pueden establecer penas indeterminadas (cfr. cc. $1319 \$ 1 ; 1315$ $\$ 2$; vide 3.1.2).

- Se pueden establecer censuras (c. $1312 \$ 1,1^{\circ}$ ), tanto ferendae sententiae como latae sententiae (cfr. cc. $1319 \$ 2$ y 1318; 1314; vide 3.1), pero no debe hacerse si no es para los delitos más graves y conforme al c. 1318.

- Se pueden establecer otras penas expiatorias (vide 3.2) también latae sententiae para delitos con las características descritas por el c. 1318. 


\section{Tipos de PENAS PREVISTAS EN EL CIC}

3.1. Distinciones previas. En las normas relativas a las penas, el CIC se refiere, explícita o implícitamente, a ciertos conceptos y distinciones, algunos ya mencionados, que es necesario conocer para interpretar y aplicar rectamente esas disposiciones.

\subsubsection{Penas «ferendae sententiae» $y$ «latae sententiae»:}

- Conforme al c. 1314, la pena por un delito generalmente es ferendae sententiae; es decir, cuando se comete la infracción tipificada por una ley o por un precepto, debe ponerse en marcha el proceso penal para imponer la pena mediante sentencia judicial (cfr. cc. 1721 ss.), o el procedimiento administrativo (cfr. c. 1720) para imponerla mediante decreto penal (vide 2.4.2.1; 7).

- Sin embargo, en casos muy graves y siempre de manera expresa (cfr. cc. 1314, 1318), la ley o el precepto que la establecen (vide 2.4) pueden disponer que la pena sea latae sententiae. En estos supuestos el derecho mismo aplica la pena ipso facto -sin que sea necesario adoptar la decisión de imponerla, porque esta viene ya dada (lata) por la norma- en cuanto se produce la infracción, siempre con los demás requisitos establecidos por el derecho (cfr. cc. 1321; $1324 \$ 3$ ).

\subsubsection{Penas indeterminadas y penas facultativas:}

- La pena se llama indeterminada (cfr. c. $1315 \$ 2$ ), cuando la ley penal, al tipificar un delito, establece (usando la fórmula «iusta poena puniatur», u otras similares) que esa conducta será castigada, pero no precisa -o lo hace solo en cierta medida: p. e. diciendo de qué tipo ha de serla sanción que corresponderá. Por tanto, si la ley particular no ha determinado previamente (con carácter general) una pena que la ley universal establece como indeterminada (cfr. c. $1315 \$ 3$ ), el juez o el superior deberán determinarla en la sentencia o en el decreto con el que se imponga la pena por ese delito (atendiendo siempre a las indicaciones de la norma que la establece y a las generales del CIC).

- El precepto penal, como se ha indicado, no puede conminar con una pena indeterminada (cfr. c. $1319 \$ 1$ ).

- Una pena es facultativa (cfr. c. $1315 \$ 3$ ), si la ley que tipifica el delito no utiliza una expresión preceptiva sino potestativa (p. e. «puniri po- 
test», en lugar de «puniatur» o «puniri debet», etc.), que otorga a la autoridad competente la facultad de decidir, con arreglo a derecho, si imponer o no la pena después de valorar prudentemente las circunstancias del caso.

3.2. Censuras y penas expiatorias. Las penas previstas por el derecho canónico pertenecen a uno de esos dos tipos (cfr. c. $1312 \$ 1$ ).

- Las censuras son llamadas también penas medicinales, porque tienden de un modo peculiar a la enmienda del delincuente (sin excluir, claro está, los demás fines de la pena: vide 1.2), lo que se manifiesta claramente en su estructura y en su régimen jurídico.

- Las penas expiatorias, por su parte, no son necesariamente menos graves, ni dejan de perseguir también todas las finalidades generales del derecho penal canónico, pero no tienen la vinculación estructural con la enmienda del delincuente que caracteriza a las censuras.

3.2.1. Las censuras en general. Las censuras son: la suspensión (que puede imponerse solo a los clérigos), el entredicho y la excomunión. Estas penas tienen algunas características comunes:

- Solo pueden imponerse a los delincuentes contumaces (aquellos que persisten en su actitud y rechazan los medios que se ponen para conseguir su enmienda).

- Como consecuencia de lo anterior, es inválida la imposición de una censura si no se ha amonestado previamente, al menos una vez, al delincuente para que cese en su contumacia, dándole un tiempo prudencial para que se enmiende (cfr. c. $1347 \$ 1$ ). No es necesaria esta amonestación previa cuando se trata de una censura latae sententiae (vide 3.1 .1 ), ni cuando la censura ha sido conminada por un precepto penal (vide 2.4.2).

- El supuesto de esta amonestación es distinto del previsto en el c. 1339 $\$ 1$ : allí se amonesta, como remedio penal (vide 3.2.3), a quien se encuentra en ocasión próxima de delinquir, o a aquel de quien se sospecha que ha cometido un delito; aquí se amonesta a quien ya ba delinquido ciertamente, para tratar de que se arrepienta y rectifique sin necesidad de imponer la censura y, a la vez, como requisito previo para imponerla válidamente si es necesario. No obstante, las indicaciones 
del c. $1339 \$ \$ 1$ y 3 sobre el modo de hacer la amonestación y de dejar constancia formal de ella, sirven de orientación útil.

- Las censuras no pueden ser perpetuas, sino que el reo tiene derecho a ser absuelto (en sentido jurídico) cuando abandona la contumacia (cfr. cc. $1358 \$ 1 ; 1347 \$ 2)$.

- Las censuras latae sententiae no son exactamente automáticas, ya que se requiere, como siempre, que los delitos correspondientes resulten gravemente imputables, extremo que el derecho refuerza con requisitos específicos (vide 2.3.4). Por esa razón, si bien es posible afirmar en abstracto que quien cometa tal infracción incurre en tal censura latae sententiae, en cambio para poder decir si un infractor concreto ha incurrido efectivamente en la pena -muchas veces será necesario poder decirlo oficialmente, p. e., para reparar el escándalo causado por una conducta pública o notoria- es preciso que se compruebe cuál es verdaderamente su situación penal y se declare, tras un proceso judicial o un procedimiento administrativo. Se deben seguir fundamentalmente los mismos pasos que para la imposición de las penas ferendae sententiae (cfr. c. 1341; vide 7).

- El acto jurídico de declaración (sentencia o decreto) no impone la pena latae sententiae que, como se ha visto, ya estaría impuesta por el derecho, en su caso: tiene solamente efectos declarativos. Sin embargo, el hecho de que una censura sea declarada o no tiene consecuencias jurídicas importantes, en cuanto a los efectos (cfr. cc. $1331 \$ 2,1332 \$ 3$ ), la obligatoriedad de la pena (cfr. cc. 1335 y $1352 \$ 2$ ) y su remisión (cfr. cc. 1355-1357).

3.2.1.1. La excomunión. Es la censura más grave. El reo que incurre en excomunión queda afectado por extensas prohibiciones en aspectos fundamentales de la plena comunión eclesiástica: no puede celebrar sacramentos o sacramentales, ni recibir los sacramentos; no puede participar activamente en celebraciones de culto; no puede desempeñar oficios, ministerios o cargos eclesiásticos ni realizar lícitamente actos de potestad de jurisdicción (cfr. c. $1331 \$ 1)$.

- Si la excomunión es impuesta o declarada (vide 3.2.1), por sentencia o decreto penal, a esos efectos generales se añaden los que prevé el c. $1331 \$ 2$, que no se dan en los casos de excomunión latae sententiae no declarada. 
3.2.1.2. El entredicho. Aunque esta censura no afecta directamente a la comunión jurídica del reo con la Iglesia, ni le impide el ejercicio de otras funciones, le acarrea las mismas prohibiciones que la excomunión (cfr. c. 1332 $\$ 1$ ) en cuanto a los sacramentos (celebración y recepción), sacramentales y actos de culto (con iguales efectos también si es declarado: cfr. c $1332 \$ 4$ ), salvo que la ley o el precepto penal determinen de otro modo algunos de sus efectos (cfr. c. $1332 \$ 2$ ).

- Parece técnicamente difícil imponer penas, también la de entredicho, con los requisitos del derecho canónico, a una persona jurídica (cfr. c. 115), pues, en cuanto sujeto colectivo o patrimonial, propiamente no puede delinquir, ya que, p. e., sería imposible valorar unitariamente los necesarios requisitos de imputabilidad (vide 2.3) y contumacia (vide 3.2.1), etc. Fuera del ámbito estrictamente penal, hay otras actuaciones posibles, en ejercicio del deber de vigilancia de la autoridad competente sobre la vida y actividad de las personas jurídicas: cfr. cc. $120,305,318,320,326$, etc.

- En cambio, las personas físicas podrían incurrir en una pena por razón de actividades relacionadas directamente con personas jurídicas (cfr. c. $1332 \$ 4)$, sobre todo por acciones delictivas llevadas a cabo como parte de sus órganos de gobierno o representación. También podría ser delictivo el hecho de permanecer o inscribirse en una asociación determinada (aparte del supuesto general previsto por el c. 1374), p. e., después de que el Ordinario competente hubiera dado un precepto penal legítimo para prohibirlo por causas graves.

3.2.1.3. La suspensión. Por esta censura se prohíbe a un clérigo, total o parcialmente (dentro de ciertos límites (cfr. c. $1333 \$ 3$ ), el ejercicio de la potestad de orden, de la potestad de jurisdicción (incluso bajo pena de invalidez de los actos, si la ley o el precepto así lo expresan: cfr. c. $1333 \$ 2)$ o de los derechos y funciones propios de su oficio (cfr. c. $1333 \$ 1$ ); así como la percepción de ciertos bienes (cfr. c. $1333 \$ 4$ ).

- La ley o el precepto pueden determinar el ámbito de la suspensión para delitos concretos, con arreglo al c. 1334.

- Solo la ley universal o particular -no el precepto- puede establecer una pena de suspensión latae sententiae sin determinar su alcance (dentro de los límites previstos por el c. 1333). En ese caso, se entenderá que los 
efectos de la suspensión son todos los indicados en el c. $1333 \$ 1$ (cfr. c. 1334).

- Cuando esa suspensión latae sententiae se establece, en cambio, por precepto penal (cfr. c. $1334 \$ 1$ ), debe determinarse siempre su ámbito (podría abarcar todo lo previsto por el c. $1333 \$ 1$, sin embargo no puede establecerlo con una expresión genérica, como la ley, sino que debe determinarlo explícitamente: cfr. c. 1334 \$2).

- También cabe que la sentencia o el decreto penal determinen el alcance de la suspensión ferendae sententiae al aplicarla (cfr. c $1334 \$ 1$ ).

3.2.2. Penas expiatorias. Consisten en la privación de algún bien espiritual o temporal impuesta legítimamente a un fiel (en forma de obligación, prohibición, privación, inhabilitación, expulsión, etc.), siempre de manera congruente con el fin sobrenatural de la Iglesia (cfr. c. $1312 \$ 2$ ).

- Solo pueden (cfr. c. $1338 \$ 1$ ) afectar a bienes -facultades, derechos, potestades, habilidades, etc.- que estén bajo la potestad de la autoridad que establece la pena (es decir, la que la prevé, que puede no ser la misma que la impone).

- A diferencia de las censuras, las penas expiatorias pueden ser perpetuas o imponerse por un tiempo, determinado o indeterminado (cfr. c. $1336 \$ 1$ ).

- El CIC ofrece un elenco de posibles penas expiatorias, entre otras que pudieran establecerse (cfr. c. $1312 \$ 2$ ).

- Solo las prohibiciones mencionadas en el c. $1336 \$ 1,3^{\circ}$ pueden ser latae sententiae (cfr. c. $1336 \$ 2$ ), no así las demás penas expiatorias.

3.2.3. La pena expiatoria de expulsión del estado clerical. La dimissio e statu clericali (cfr. c. $290,2^{\circ}$ ) es siempre, por su misma naturaleza, una pena expiatoria perpetua. Como se ha recordado ya, no puede ser instituida por ley particular ni por precepto: el c. 1317 la reserva a la ley universal (tampoco puede ser elegida, en el momento de imposición de la pena, en los casos en que la ley establece una pena indeterminada para un delito: vide 3.1.2; 8.4.3).

- El legislador no establece la obligación de imponer esta pena como primera y única posibilidad para ninguno de los delitos tipificados en el CIC. Por el contrario, la constituye siempre como extremo superior de una escala que gradúa de modo ascendente la actuación penal, permitiendo llegar hasta la dimissio en los casos más graves. Los cánones 
que recogen los supuestos previstos, utilizan expresiones como: «non exclusa dimissione e statu clericali», «puniri potest dimissione e statu clericali», «in casibus gravioribus dimittatur e statu clericali», «gradatim privationibus ac vel etiam dimissione e statu clericali puniri debet», «aliae poenae gradatim addi possunt usque ad dimissionem e statu clericali» (cfr. cc. $1364 \$ 2,1370 \$ 1,1394 \$ 1,1395 \$ \$ 1-3$ ).

- Este modo de legislar, que resulta lógico, dada la naturaleza de la pena, exige tanto prudencia como fortaleza a la hora de valorar las circunstancias del caso concreto para imponerla.

3.3. Remedios penales y penitencias. Además de las sanciones penales, el c. $1312 \$ 3$ prevé el uso de remedios penales (amonestación, reprensión), sobre todo para prevenir el delito; y penitencias, para añadirlas a la pena o para sustituirla en ciertos casos. La decisión de aplicar un remedio penal o una penitencia debe adoptarse por decreto (cfr. c. $1342 \$ 1$ ).

3.3.1. Los remedios penales en general. La amonestación (cfr. c. $1339 \$ 1)$ y la reprensión (cfr. c. $1339 \$ 2$ ) son competencia del Ordinario, que puede designar a otra persona para llevarlas a cabo.

- Tanto la amonestación como la reprensión de que se trata aquí, además de medidas de solicitud pastoral, son actos formales, que pueden adquirir relevancia jurídica en distintos supuestos, por eso debe quedar siempre constancia documental de ellas (cfr. c. 1339 \$3), sin que tengan que ser necesariamente públicas. El carácter formal distingue estos dos remedios penales de otro tipo de advertencias o indicaciones que pudiera hacer el Ordinario a los fieles, clérigos o no, acerca de su conducta en cualquier materia, sin que quede especial constancia de ellas. Además, los remedios penales se refieren siempre a situaciones más o menos próximas al comportamiento delictivo.

- El CIC no especifica el procedimiento que debe seguirse para satisfacer la exigencia de que quede alguna constancia documental de estos remedios penales, por lo que caben diversas posibilidades.

- P. e., el Ordinario, o la persona por él designada, puede citar al interesado y entregarle el texto de la amonestación o de la reprensión, para que lo lea en su presencia. Una vez leído y aclarados los extremos necesarios, deben firmar los dos, indicando la fecha. Si se prevé que este 
procedimiento puede presentar dificultades (p. e., porque el interesado se niegue a firmar), o si se quiere hacer oralmente, sería necesario que actuase, además del Ordinario o la persona designada por él, algún notario para dar fe de lo actuado. El documento deberá conservarse en el archivo secreto de la curia (cfr. c. 489).

3.3.1.1. La amonestación. Está indicada, en primer lugar, como medida preventiva para los casos en que alguien se encuentra en ocasión próxima de cometer un delito (cfr. c. $1339 \$ 1$ ).

- El Ordinario deberá valorar prudentemente (con criterios análogos a los que emplea la moral) si una conducta puede ser calificada como ocasión próxima de delinquir. No es necesario, sin embargo, que realice para ello una especial investigación, ya que no se trata de una pena: basta la previsión prudente de que determinada conducta, si no se rectifica, podría acabar desembocando en algún delito, p. e. contra la fe, o contra obligaciones específicas de un oficio. En efecto, la eficacia preventiva de este remedio dependerá de que se emplee a tiempo, con diligencia, cuando hay motivo razonable, sin arriesgarse a que el delito se consume por temor a errar o por un desproporcionado afán de certeza.

- El c. $1339 \$ 1$ dispone que se puede usar también la amonestación en otros casos en que, una vez concluida la investigación previa de un posible delito (cfr. c. 1717; vide 6), el Ordinario, conforme al c. $1718 \$ 1$, $1^{\circ}$, considera que no se puede promover un proceso o un procedimiento administrativo para la imposición de la pena (p. e. porque prevé que no sería posible probar el delito y habría que absolver al acusado), y sin embargo tiene la grave sospecha de que el investigado puede haber cometido un delito. En estos supuestos la amonestación formal tiene la función de hacer cesar la posible conducta delictiva, o evitar que se repita.

3.3.1.2. La reprensión. El c. $1339 \$ 2$ prevé la reprensión o corrección para los casos en que la conducta de alguien cause escándalo o grave perturbación del orden.

- Puesto que la corrección debe ser adecuada a las características de la persona y del hecho, cuando se trata de una conducta externa que, sin 
ser delictiva, causa escándalo, el Ordinario deberá plantearse si es oportuno contrarrestarla dando una publicidad proporcionada al hecho de la corrección o incluso a su contenido o a alguno de sus términos, además de dejar constancia documental del modo indicado (vide 3.3.1).

- Nada impide que se acumulen -incluso en el mismo acto, pero distinguiendo ambos remedios penales en el documento en que se hagan constar- la corrección y la amonestación, puesto que la misma conducta de una persona puede incluir aspectos ya pasados que exijan la primera y otros futuros o ignorados (la ocasión próxima de delinquir si no se rectifica, o la sospecha antes descrita: vide 3.3.1.1) que hagan apropiada la segunda conforme a derecho.

3.3.2. Posible uso de un precepto penal como remedio penal. Si la amonestación y las correcciones hechas a alguien, incluso reiteradamente, han sido ineficaces y es previsible que lo seguirán siendo, el Ordinario podría dar un precepto penal (vide 2.4.2) en el que mande detalladamente qué debe hacer o evitar el interesado, y establezca al mismo tiempo la pena en que incurrirá en caso de desobediencia.

- Si alguna de las conductas que se trata de evitar o corregir están ya tipificadas como delito por la ley, el precepto penal deberá limitarse a recoger lo dispuesto a ese respecto (determinando, si es el caso, la pena indeterminada prevista por la ley). En cambio, para otras conductas escandalosas, o que puedan constituir ocasión próxima de delinquir, etc., pero que no estén previamente tipificadas como delito, podrá establecer penas, siempre determinadas (vide 3.1.2). El mismo precepto puede referirse a diversas conductas, recordando para unas las consecuencias penales ya previstas por el derecho y estableciendo para otras las consecuencias penales que producirán para el interesado si no obedece al precepto respecto a ellas.

3.3.3. Las penitencias. De acuerdo con el c. $1340 \$ 1$, consisten en el mandato de realizar alguna obra de caridad, piedad o religión (p. e., una limosna, un tiempo de retiro, una lectura determinada, unas oraciones, etc.).

- Pueden imponerse en el fuero externo (es decir, al margen tanto del sacramento de la penitencia, como del fuero interno sacramental y de 
los demás supuestos de ejercicio no público de la potestad de régimen: cfr. c. 130), a no ser que sean por transgresiones ocultas (cfr. c. 1340 $\$ 2$ ), no públicas ni notorias.

- Por transgresiones ocultas solo pueden imponerse penitencias en el fuero interno (sacramental o no), ya que de lo contrario se correría el riesgo de infamar al interesado (esto no significa que los actos que se manda realizar tengan que ser internos u ocultos, sino que la imposición de la penitencia -o sea, la razón por la que el sujeto va a llevar a cabo esos actos- no se realiza con la publicidad que normalmente tienen los actos de la autoridad, según la naturaleza de cada uno).

- Las penitencias se pueden añadir a los remedios penales, conforme al c. $1340 \$ 3$.

- Se pueden usar para sustituir a una pena en los casos previstos por el derecho: cuando, por las circunstancias que concurren y por las disposiciones del delincuente, resulta ya innecesaria o desproporcionada (cfr. cc. 1343; 1344, $2^{\circ} ; 1348$ ).

- En algunos casos, se pueden añadir a una pena (cfr. c. 1312 \$3), p. e. buscando reforzar su eficacia para procurar la enmienda del delincuente, o también para agravarla cuando, teniendo en cuenta las circunstancias, la pena prevista por el derecho resulta de algún modo insuficiente o menos eficaz.

- Por último, pueden imponerse al remitir una censura (cfr. c. 1358).

\section{Principales delitos tipificados en Derecho canónico}

4.1. Los bienes protegidos mediante el derecho penal. Los delitos que tipifica el derecho canónico, previendo al mismo tiempo las penas para cada uno de ellos, se agrupan en torno a determinados valores eclesiales que el legislador quiere proteger especialmente, porque son de gran trascendencia para la existencia y misión de la Iglesia. Concretamente, los que tipifica el CIC en los cc. 1364 ss. se centran en los tres ámbitos en que se expresa jurídicamente la comunión (cfr. c. 205) y en algunos aspectos fundamentales de la dignidad humana y cristiana. Por su parte, los llamados delicta graviora, que incluyen los delitos más graves cometidos contra la fe y la moral o en la celebración de los sacramentos, se reservan a la Congregación para la Doctrina de la Fe $[\mathrm{CDF}]$, están tipificados en parte en el CIC y en parte en el 
Motu proprio Sacramentorum Sanctitatis Tutela [SST], al que se remitirá cuando sea oportuno.

- En esta guía simplemente se enumeran, a modo de elenco, los principales delitos tipificados, indicando cuáles están reservados a la Santa Sede y en qué aspecto, ya que lo que se reserva es, unas veces, la competencia para conocer judicial o administrativamente y sancionar el delito (o declararlo, si está castigado con una pena latae sententiae: vide 3.2.1); y otras, la competencia para remitir o levantar la pena ya impuesta conforme a derecho («censuras reservadas»: cfr. c. 1354 $\$ 3)$.

- Para el discernimiento detallado de los supuestos concretos -los tipos delictivos, como se dirá, están sujetos a interpretación estricta y no cabe extenderlos por analogía: vide 7.1-, se remite a los comentarios más usuales de los cánones correspondientes y a los manuales citados en la breve bibliografía que se incluye al final de esta guía.

4.2. Delitos tipificados en el CIC y en SST. Para estructurar mínimamente el elenco, se usarán las categorías con las que el CIC agrupa los delitos, añadiendo en cada grupo, si es el caso, los delitos o las especialidades que añade SST.

4.2.1. Delitos contra la religión y la unidad de la Iglesia:

- Apostasía, herejía y cisma (cfr. cc. 756 y 1364; SST, art. 2).

- Communicatio in sacris prohibida (cfr. cc. 844 y 1365). El conocimiento del delito consistente en concelebrar con ministros de comunidades eclesiales que no tienen la sucesión apostólica ni reconocen la sacramentalidad del sacerdocio está reservado a la CDF (cfr. SST, art. $3 \$ 1$, $\left.4^{\circ}\right)$.

- Entrega de los hijos para que sean bautizados o educados en una religión acatólica (cfr. c. 1366).

- Profanación de las especies consagradas, consistente en arrojarlas por tierra deliberadamente y con grave desprecio o llevárselas o retenerlas con un fin sacrílego (cfr. c. 1367). El conocimiento de estos delitos está reservado a la CDF (cfr. SST, art. $3 \$ 1,1^{\circ}$ ). El m.p. tipifica además el delito consistente en consagrar una especie o ambas fuera de la misa con un fin sacrílego (cfr. SST, art. $3 \$ 2$ ). La declaración y la remisión 
de la correspondiente censura de excomunión latae sententiae están reservadas a la Sede Apostólica.

- Perjurio ante la autoridad eclesiástica (cfr. c. 1368).

- Servirse de un espectáculo, una reunión pública o un medio de comunicación para blasfemar, atentar gravemente contra las buenas costumbres, injuriar a la religión o a la Iglesia o suscitar odio o desprecio contra ellas (cfr. c. 1369).

4.2.2. Delitos contra autoridades eclesiásticas y contra la libertad de la Iglesia:

- Atentado contra el Romano Pontífice. La remisión de la censura de excomunión latae sententiae está reservada a la Sede Apostólica (cfr. c. $1370 \$ 1)$.

- Atentado contra un Obispo (cfr. c. 1370 \$2).

- Violencia física contra un clérigo o contra un religioso o una religiosa, en desprecio de la fe, de la Iglesia, de la potestad eclesiástica o del ministerio (cfr. c. $1370 \$ 3$ ).

- Enseñanza obstinada de una doctrina condenada por el Romano Pontífice o por un Concilio Ecuménico (cfr. c. 1371, 1º).

- Rechazo pertinaz de una doctrina propuesta definitivamente por el Romano Pontífice o por el Colegio de los Obispos sobre fe y costumbres, sin retractarse después de haber sido amonestado por la Sede Apostólica o por el Ordinario (cfr. c. 1371, $1^{\circ}$ ).

- Desobediencia al mandato o prohibición legítimos de la Sede Apostólica, del Ordinario o del Superior, que persiste tras haber sido amonestado el sujeto (cfr. c. $1371,2^{\circ}$ ).

- Recurso al Concilio Ecuménico o al Colegio de los Obispos contra un acto del Romano Pontífice (cfr. c. 1372).

- Suscitar públicamente la aversión o el odio de los súbditos contra la Sede Apostólica o el Ordinario con motivo de un acto de potestad o de ministerio, o incitar a la desobediencia (cfr. c. 1373).

- Inscripción en una asociación que maquina contra la Iglesia (cfr. c. 1374).

- Promoción o dirección de una asociación que maquina contra la Iglesia (cfr. c. 1374).

- Impedimento del libre ejercicio del ministerio, de una elección o de la potestad eclesiástica (cfr. c. 1375).

- Impedimento del legítimo uso de los bienes eclesiásticos (cfr. c. 1375). 
- Intimidación de un elector, del elegido o de quien ejerció una potestad o un ministerio eclesiásticos (cfr. c. 1375).

- Profanación de una cosa sagrada, mueble o inmueble (cfr. cc. 1171 y 1376).

- Enajenación de bienes eclesiásticos sin la licencia requerida por el derecho (cfr. cc. 1257, 1291 ss. y 1377).

\subsubsection{Usurpación de funciones eclesiásticas y delitos en su ejercicio:}

- Atentado de celebración de la Eucaristía sin ser sacerdote. El conocimiento de este delito está reservado a la CDF (cfr. c. $1378 \$ 2,1^{\circ}$; SST, art. $3 \$ 1,2^{\circ}$ ).

- Simulación de la celebración eucarística. El conocimiento de este delito está reservado a la CDF (cfr. c. 1379; SST, art. $3 \$ 1,3^{\circ}$ ).

- Absolución del cómplice en pecado contra el sexto mandamiento. El conocimiento de este delito está reservado a la CDF; y la remisión de la censura de excomunión latae sententiae está reservada a la Sede Apostólica (cfr. c. $1378 \$ 1$; SST, art. $4 \$ 1$ ).

- Atentado de absolución sacramental o simple escucha de una confesión sacramental sin poder hacerlo válidamente. El conocimiento de este delito está reservado a la CDF (cfr. c. $1378 \$ 2,2^{\circ}$; SST, art. $4 \$ 1$, $\left.2^{\circ}\right)$.

- Simulación de la absolución sacramental. El conocimiento de este delito está reservado a la CDF (cfr. c. 1379; SST, art. $4 \$ 1,3^{\circ}$ ).

- Solicitación del confesor al penitente durante la confesión o con ocasión o pretexto de ella para que cometa un pecado contra el sexto mandamiento (cfr. c. 1387). Si la solicitación es para cometer un pecado con el propio confesor, el conocimiento del delito está reservado a la CDF (cfr. SST, art. $4 \$ 1,4^{\circ}$ ).

- Violación directa o indirecta del sigilo sacramental por el confesor (cfr. c. $1388 \$ 1)$. El conocimiento de ambos delitos está reservado a la $\mathrm{CDF}$; la pena del primero es censura de excomunión latae sententiae reservada a la Sede Apostólica (cfr. SST, art. $4 \$ 1,5^{\circ}$ ).

- Violación del secreto de confesión por el intérprete y por quienes, de algún modo, hubieran tenido conocimiento de los pecados por la confesión (cfr. c. $1388 \$ 2$ ).

- Registrar por cualquier medio técnico o divulgar con malicia en un medio de comunicación las palabras del confesor o del penitente, sea 
la confesión verdadera o fingida, propia o de otra persona. El conocimiento de este delito está reservado a la CDF (cfr. c. 1388; SST, art. 4 $\$ 2)$.

- Simulación de la administración de un sacramento de otro modo no tipificado específicamente (cfr. c. 1379).

- Celebración o recepción de un sacramento con simonía (cfr. c. 1380).

- Usurpación de un oficio eclesiástico o retención ilegítima del oficio después de haber sido privado de él o haber cesado (cfr. c. 1381).

- Consagración episcopal (activa y pasiva) sin mandato pontificio. La remisión de la censura de excomunión latae sententiae en que se incurre por este delito está reservada a la Sede Apostólica (cfr. c. 1382).

- Ordenación de un súbdito ajeno sin las dimisorias legítimas, y recepción de la ordenación en esas circunstancias (cfr. cc. 1015 y 1383).

- Atentado de ordenación de una mujer. El conocimiento de este delito está reservado a la CDF. También está reservada a la Sede Apostólica la remisión de la censura de excomunión latae sententiae en que incurren quienes lo cometen (cfr. SST, art. 5).

- Ejercicio ilegítimo de una función sacerdotal o de otro ministerio sagrado, de cualquier modo no tipificado específicamente (cfr. c. 1384).

- Lucro ilegítimo con los estipendios de misas (cfr. c. 1385).

- Soborno de quien ejerce una función en la Iglesia, con promesas o dádivas, para que haga u omita ilegítimamente algo (cfr. c. 1386).

- Aceptación de los sobornos indicados en el punto anterior (cfr. c. 1386).

- Abuso de potestad o de cargo eclesiásticos (cfr. c. 1389 \$1).

- Realización u omisión ilegítima y con daño ajeno de un acto de potestad, función o ministerio eclesiásticos por negligencia culpable (cfr. c. $1389 \$ 2)$.

\subsubsection{Delitos de falsedad:}

- Denuncia falsa ante la autoridad eclesiástica de un confesor por el delito de solicitación en confesión (cfr. c. $1390 \$ 1$ ).

- Denuncia calumniosa de un fiel ante el superior eclesiástico por algún delito (cfr. c. $1390 \$ 2$ ).

- Lesión de la buena fama de alguien ante el superior eclesiástico (cfr. c. 1390 \$2). 
- Falsificación de un documento público eclesiástico y alteración, destrucción u ocultación de uno verdadero (cfr. c. 1391, $1^{\circ}$ ).

- Utilización en el ámbito eclesiástico de un documento (eclesiástico o no) falso o alterado (cfr. c. $1391,2^{\circ}$ ).

- Afirmación de una falsedad en un documento público eclesiástico (cfr. c. $\left.1391,3^{\circ}\right)$.

\subsubsection{Delitos contra obligaciones especiales:}

- Ejercicio ilegítimo del comercio o de los negocios por parte de clérigos y religiosos (cfr. c. 1392).

- Incumplimiento de la pena legítimamente impuesta (cfr. c. 1393).

- Atentado de contraer matrimonio, incluso solo civilmente, por parte de un clérigo o de un religioso de votos perpetuos (cfr. cc. 1087; 1088; 1394).

- Concubinato de un clérigo, o permanencia con escándalo en otro pecado externo contra el sexto mandamiento (cfr. c. $1395 \$ 1$ ).

- Cualquier otro pecado externo contra el sexto mandamiento -en su caso, con persona mayor de 18 años- que un clérigo cometa con violencia o amenazas o públicamente (cfr. c. $1395 \$ 2$ ).

- Pecado externo contra el sexto mandamiento cometido por un clérigo con persona menor de 18 años o con persona que habitualmente tenga un imperfecto uso de razón. El conocimiento de este delito está reservado a la CDF (cfr. c. $1395 \$ 2$; SST, art. $6 \$ 1,1^{\circ}$, que modifica en cuanto a la edad del menor el c. 1395).

- Adquisición, retención o divulgación, en cualquier forma y con cualquier instrumento, por parte de un clérigo, con fin libidinoso, de imágenes pornográficas de menores de edad inferior a 14 años. El conocimiento de este delito está reservado a la CDF (cfr. SST, art. $6 \$ 1,2^{\circ}$ ).

- Incumplimiento grave de la ley de residencia a la que alguien está obligado por su oficio eclesiástico (cfr. c. 1396).

\subsubsection{Delitos contra la vida y la libertad del hombre:}

- Homicidio (cfr. c. 1397).

- Secuestro o retención de alguien con violencia o engaño (cfr. c. 1397).

- Mutilación o lesiones graves (cfr. c. 1397).

- Aborto consumado (cfr. cc. 1329 y 1398). 


\section{PROCEDIMIENTO}

\section{LA NOTICIA DE UN POSIBLE DELITO, COMIENZO DE LAS ACTUACIONES}

5.1. Noticia de un posible delito y reacción del Ordinario. Con arreglo al c. $1717 \$ 1$, el Ordinario debe reaccionar «siempre» activamente cuando tiene noticia, al menos verosímil, de un posible delito.

- El concepto de «noticia» incluye el conocimiento obtenido por cualquier cauce: directo (por ciencia propia); o indirecto: denuncia, queja o informe de algún fiel; informaciones de prensa; fama o vox populi, etc.

- La obligación no se limita a los casos en que se tenga noticia de un delito efectiva y ciertamente cometido, sino que se refiere a toda noticia de un posible delito, de una conducta que podría ser delictiva, si la noticia responde a la verdad.

- La reacción activa del Ordinario en esos casos consiste, ante todo, en valorar la verosimilitud de la noticia para abrir una investigación previa (vide 6), si es preciso. Resultaría imprudente e injusto -y por eso lo prohíbe el derecho canónico-, tanto actuar penalmente de modo inmediato en respuesta a cualquier noticia, como inhibirse sin valorarla.

5.2. Valoración de la verosimilitud de la noticia. Para que surja el deber de decretar que se abra la investigación previa (cfr. c. 1717 \$1; vide Anexo, 1 y 3), no se requiere que el Ordinario alcance la misma certeza que sería necesaria para imponer la pena (cfr. c. $1720,3^{\circ}$ ). Basta que la noticia presente elementos que la hagan verosimil: p. e., hechos posibles, fuentes fiables, relatos creíbles, coincidencia de tiempos y lugares, congruencia con noticias o indicios anteriores menos concretos, etc.

- En la práctica, el Ordinario debería investigar, al menos someramente, siempre que la noticia no sea claramente falsa o del todo inverosímil (vide 5.4.1; Anexo, 1 y 2) y se refiera a hechos que, de haber sucedido realmente, constituirían un delito (vide 2.1) o al menos podrían considerarse prudentemente una «ocasión próxima de delinquir» (cfr. c. $1339 \$ 1)$.

5.3. Tratamiento de una posible denuncia anónima. En esta fase de la actuación no se trata todavía de iniciar un procedimiento penal (vide 7), sino solamente de decidir si se debe investigar. Por tanto, una noticia verosímil proce- 
dente de una denuncia anónima podría ofrecer base suficiente para poner en marcha una cauta y prudente investigación.

- Sin embargo, si se decidiera después iniciar la actuación penal propiamente dicha, esa decisión (y, lógicamente, la de imponer la pena, en su caso) no podría basarse ya solo en la denuncia anónima, sino que necesitaría apoyarse en datos y elementos de prueba suficientes, obtenidos en la investigación.

5.4. Casos en que resulta superflua la investigación. El Ordinario puede abstenerse lícitamente de realizar la investigación cuando «parezca del todo superflua» (c. $1717 \$ 1)$. Esto puede suceder, especialmente en los supuestos que se indican a continuación.

5.4.1. Noticia inverosimil o ciertamente falsa. Cuando la noticia es claramente inverosímil o al Ordinario le consta con certeza (a partir de datos objetivos que conoce ciertamente, no solo basándose en su opinión subjetiva) que no se ha cometido el delito del que le llega noticia.

- En este caso, el Ordinario no debe simplemente inhibirse, sino que ha de tomar formalmente la decisión de no investigar (vide Anexo, 1 y 2). Para ello conviene que emita un decreto singular (cfr. cc. 48 ss.) que formalice esa decisión, exprese sus motivos (no basta decir que la noticia es inverosímil o falsa; hay que explicar, al menos sintéticamente, por qué se hace esa valoración: cfr. c. 51) y mande archivar las actuaciones relacionadas con esa noticia de un posible delito. El decreto se archivará con su expediente en el archivo secreto (cfr. c. 1719).

- Este modo de proceder resulta oportuno, no solo porque el c. $1717 \$ 1$ dice literalmente: «decernat» (es decir: «decrete»), sino también porque de este modo quedará constancia documental de que la investigación no se omite por negligencia o lenidad de la autoridad eclesiástica, sino en virtud de una decisión explícita y motivada, adoptada tras valorar en conciencia y conforme a derecho la noticia de un posible delito.

- Por otra parte, en estos supuestos, la autoridad deberá valorar además la necesidad u oportunidad de rectificar, con más o menos publicidad según las circunstancias, las noticias erróneas o calumniosas que pudieran dañar la fama de las personas afectadas y arrojar sospechas sobre la actitud de la Iglesia respecto a supuestas conductas delictivas 
(p. e., hablando personalmente con la persona que ha denunciado falsa o erróneamente; publicando una nota o declaración, si la noticia se ha divulgado públicamente; mandando leer una nota en la misa dominical en la parroquia en la que ha corrido el rumor, etc.).

5.4.2. Existencia de elementos suficientes para proceder inmediatamente. También resultará superflua la investigación cuando el Ordinario, al recibir la noticia del delito, estime que existen elementos suficientes para iniciar, sin necesidad de ulterior investigación previa, un procedimiento o un proceso penal (en ningún caso se podría imponer directa e inmediatamente la pena en este momento).

- En este supuesto, se dará un decreto singular (vide Anexo, 5), que debe expresar dos decisiones distintas: en primer lugar, la de omitir la investigación previa, con expresión de las razones por las que se considera superflua (cfr. cc. 48, 51, $1717 \$ 1$ ); y en segundo lugar, como prescribe el c. 1718, la de iniciar de inmediato un procedimiento administrativo o un proceso judicial penal para la imposición (o declaración: 3.2.1) de la pena (vide 7).

\section{LA INVESTIGACIÓN PREVIA}

6.1. Comienzo de la investigación por decreto. Si el Ordinario considera atendible la noticia del posible delito y decide abrir la investigación previa, debe formalizar esa decisión en un decreto singular (cfr. cc. 48 ss., 1719; vide Anexo, 3).

- Este decreto contendrá también, en su caso, el nombramiento del investigador a quien se encomiendan esas diligencias, si no las lleva a cabo personalmente el Ordinario (vide 6.3), los términos exactos del mandato que se le otorga (cfr., en todo caso, c. 138) y las medidas provisionales legítimas (vide 6.2) que parezcan prudentes y discretas, si considera oportuno adoptar alguna mientras se investiga.

6.2. Posibles medidas provisionales durante la investigación. El c. 1722 prevé la posibilidad de adoptar medidas cautelares, con las condiciones que allí se establecen, solo contra el formalmente acusado, y por tanto solamente cuando ya se ha decidido iniciar el proceso (o el procedimiento administrativo) para impo- 
ner o declarar la pena. No autoriza, en cambio, la adopción, a su amparo, de esas medidas contra el investigado mientras dura la investigación, que en todo caso debe tener siempre presente lo dispuesto en el c. $1717 \$ 2$. Solo en los delitos reservados a la CDF (vide 6.9), el art. 19 del m.p. Sacramentorum Sanctitatis Tutela permite tomar las medidas del c. 1722 ya desde la apertura de la investigación previa.

- No obstante, si las circunstancias lo aconsejan (p. e., porque a priori la noticia parece verosímil y se trata de una conducta de especial gravedad; o porque se estima que se podría generar inquietud entre los fieles -p. e. porque han denunciado ante la autoridad y no ven que suceda nada, o también a causa de la investigación misma, que puede infamar al investigado-; o si hay riesgo de reincidencia, o de pérdida o destrucción de posibles pruebas, etc.), nada impide que el Ordinario (sin necesidad de vincular públicamente su decisión con la de iniciar la investigación previa, que no será pública normalmente) tome discretamente algunas medidas que no son los mandatos o prohibiciones del c. 1722 ni se apoyan en este, pero que están en todo caso entre sus atribuciones ordinarias: p. e., un precepto singular (cfr. cc. $49,58 \$ 2$ ) notificado exclusivamente al interesado (cfr. cc. 53-56); una sustitución temporal del investigado en su destino habitual por otra persona, encargándole o no una función distinta en otro lugar oportuno para salvaguardar su fama durante la investigación; etc.

- La duración de estas medidas será, como máximo, el tiempo estrictamente necesario para la investigación. Una vez terminada esta, si se decide archivar las actuaciones, las medidas cesarán. Si, en cambio, se decide proceder penalmente, deberán renovarse (si se consideran suficientes) o sustituirse por alguna de las del c. 1722, en el decreto que manda iniciar el proceso o procedimiento (vide 6.6) o en otro separado, según parezca conveniente a la vista de las circunstancias.

6.3. Quién debe investigar. En ocasiones, resultará factible y prudente que lleve a cabo la investigación personalmente el mismo Ordinario (cfr. c. 134 $\$ 1)$. Otras veces será preferible que encomiende la investigación a «una persona idónea» (c. 1717 \$1).

- La norma no especifica qué requisitos de idoneidad debe reunir el encargado de la investigación. En general, deberá tratarse de una persona prudente, discreta y, si es posible, experimentada. Puesto que el c. 1717 
$\$ 3$ equipara esta figura, a ciertos efectos, a la del «auditor», pueden resultar orientadores los requisitos que el c. $1428 \$ 2$ exige para este.

- Teniendo en cuenta las circunstancias del asunto, habrá que atender además a otras cualidades: p. e., que el investigador no tenga relación personal con los hechos o con los sujetos investigados; que su actuación no vaya a producir extrañeza ni pueda dar lugar a especulaciones que dañen la fama de las personas investigadas (cfr. c. 1717 \$2); que goce de la cualificación necesaria para valorar algún aspecto técnico de la cuestión (p. e. económico o financiero); etc. Si se trata de investigar conductas de un sacerdote, parece que sería útil que el investigador lo fuese también, como exige el derecho en tales casos para el notario (cfr. c. $483 \$ 2)$.

- Debe tenerse en cuenta asimismo que, si se encarga la investigación al vicario judicial o a otro juez, quedarán contaminados para intervenir como jueces en el proceso penal, si se decidiera llevarlo a cabo por vía judicial (cfr. c. 1717 \$), y deberían inhibirse o podrían ser recusados.

6.4. Objeto de la investigación. La tarea del investigador, conforme al c. $1717 \$ 1$, se refiere a dos aspectos:

- Aspecto objetivo: Se debe investigar, ante todo, «el hecho y sus circunstancias», para verificar si se ha producido o se está produciendo, en efecto, una conducta objetivamente delictiva; y para precisar en lo posible los datos sobre los sujetos involucrados, los hechos y las circunstancias (personales, de tiempo y lugar, etc.).

- Aspecto subjetivo: Además, se debe investigar sobre la «imputabilidad» (vide 2.3) de los hechos a la persona o a las personas investigadas (vide 2.3.7; 8.2), ya que, como se ha indicado, no siempre la materialidad de unos hechos objetivamente ilícitos o reprensibles lleva consigo responsabilidad penal.

6.5. Modo de investigar. El Ordinario debe dirigir en todo momento la investigación, que ha de llevarse a cabo con cautela y discreción (cfr. c. $1717 \$ 1$ ); y teniendo buen cuidado de evitar que, a causa de las diligencias practicadas y del modo de actuar -por acción u omisión-, se ponga en peligro la buena fama de alguien (cfr. c. $1717 \$ 2$ ), especialmente del investigado, pero también de otras personas e incluso de la Iglesia. 
- Si no investiga personalmente el Ordinario (vide 6.3), la persona designada para esa función tiene los mismos poderes y obligaciones que el derecho asigna al auditor previsto para el proceso judicial en el c. 1428 (cfr. c. 1717 \$3): le corresponde únicamente, por tanto, recoger los elementos que resulten útiles para el objeto de la investigación y ponerlos a disposición del Ordinario, actuando conforme a su mandato. Puede también, cuando surjan dudas en el desempeño de su tarea, decidir provisionalmente -en tanto el Ordinario provea- qué elementos recoger y de qué modo.

- Uno de los aspectos sobre los que hay que tomar decisiones es si informar al investigado de la investigación y sus motivos, o en qué medida hacerlo, en el caso. Puede servir de orientación lo que indica la Circular que dirigió la CDF en 2011 a las Conferencias episcopales acerca de las Líneas Guía para el tratamiento de los delitos reservados a esa Congregación: «La prudencia del Obispo o del Superior Mayor decidirá cuál será la información que se podrá comunicar al acusado durante la investigación previa». Los motivos que habrá que considerar son, p. e., la conveniencia de no inquietar quizá inútilmente al investigado; la necesidad de informaciones que solo él puede dar para la investigación; el temor de que pueda destruir pruebas u obstaculizar de otro modo la investigación, etc.

- Se debe ir formando el expediente de las diversas actuaciones (entrevistas, inspecciones, visitas, etc.) llevadas a cabo durante la investigación, con intervención de los notarios (cfr., si es el caso, c. $483 \$ 2$ ), para que todo quede debidamente documentado (cfr. c. 1719).

6.6. Conclusión de la investigación por decreto. Cuando el Ordinario considere que los elementos reunidos durante la investigación (o después de haber decidido omitirla, por superflua: vide 5.4.2) resultan suficientes para tomar una decisión (en este momento solamente sobre si se abre o no el proceso o el procedimiento penal), debe emitir un nuevo decreto singular con el que se concluye la investigación (cfr. c. $1718 \$ 1$; vide Anexo, 4).

- Se puede considerar que son «suficientes» los elementos recogidos si bastan para fundamentar la decisión que se contiene en este decreto de conclusión y se puede prever prudentemente que, aunque se continuara algún tiempo más la investigación o se hicieran nuevas diligen- 
cias complementarias, no aparecerían ya datos que llevaran a modificar lo decidido.

- En todo caso, el decreto debe ser revocado o modificado por otro si, en efecto, surgen nuevos elementos que hagan ver al Ordinario que ha de cambiar su decisión (cfr. c. $1718 \$ 2$ ).

- Antes de dar el decreto, si lo considera prudente (cfr. c. $1718 \$ 3$ ), el Ordinario puede asesorarse con dos jueces o con otros dos expertos en derecho (los jueces, en su caso, no actúan aquí en cuanto tales, sino en cuanto expertos, pero quedarán contaminados para actuar propiamente como jueces sobre este mismo asunto: vide 6.3; la lógica subyacente es la misma del c. 1447).

- En el decreto, sobre la base de las informaciones y pruebas recogidas, se debe establecer si se procede penalmente o no y, en su caso, por qué vía. Concretamente:

1) Si puede iniciarse el procedimiento para imponer una pena (cfr. c. $1718 \$ 1,1^{\circ}$ ), porque la investigación ha permitido obtener elementos en principio suficientes, desde el punto de vista objetivo y subjetivo (vide 6.4) para sostener y probar (cfr. c. 1526) la acusación.

2) $\mathrm{Si}$, supuesto que se puede, conviene hacerlo así, atendiendo al c. 1341. Esa norma pide al Ordinario que tenga cuidado de iniciar el procedimiento penal solo cuando vea (vide 6.8) que otros medios de solicitud pastoral no bastan para restablecer la justicia, conseguir la enmienda del reo y reparar el escándalo (cfr. c. $1718 \$ 1,2^{\circ}$ ).

- Esa valoración no debe hacerse con ligereza, ya que una inhibición injustificada podría suponer un delito conforme al c. 1389 (cfr. también: papa Francisco, m.p. Come una madre amorevole, 4-VI-2016).

- Naturalmente, al valorar si bastan o no otros remedios pastorales en vez del procedimiento penal, se habrán de tener en cuenta la naturaleza y gravedad del delito y del escándalo; y las posibles normas especiales aplicables en el caso.

- P. e., si la competencia pertenece a la Santa Sede (por tratarse de un delito reservado), el Ordinario inferior no podría archivar el caso y no remitirlo a la instancia competente, por estimar que «no conviene» proceder, sobre la base de los cc. $1718 \$ 1,2^{\circ} \mathrm{y}$ 1341 (vide 6.9). 
3) $\mathrm{Si}$, en su caso, se procederá por vía judicial o -con justas causas y siempre que el derecho no lo prohíba (cfr. c. 1342)- extrajudicialmente, es decir «por vía administrativa» (cfr. c. $1718 \$ 1,3^{\circ}$ ). Esta guía se limita a ilustrar el modo de proceder en esta segunda posibilidad. Cuando se opta por la vía judicial, que es la que el derecho favorece por las mayores garantías que ofrece al acusado de un delito, ha de seguirse lo previsto en los cc. 1721 y siguientes).

4) Si el Ordinario decide que no se ha de actuar penalmente, porque de la investigación resulta claramente la inocencia del investigado, o porque no se han obtenido pruebas suficientes para iniciar un proceso, el decreto debe concluir ordenando que se archive el expediente.

- El c. 1719 manda que se archiven en el archivo secreto de la curia (cfr. c. 489) las actas de la investigación y los decretos del Ordinario con que se inicia y concluye esta. Ambos han de ser decretos debidamente motivados (cfr. c. 51). Se han de archivar también en el mismo expediente todos los documentos que preceden a la investigación (es decir, los relativos a la noticia verosímil del delito que la motivó).

6.7. La cuestión de los daños. La conducta delictiva, en muchas ocasiones (dependiendo de su naturaleza), además de las consecuencias penales, puede dar también lugar a la obligación de reparar o resarcir daños causados por la actividad del acusado (cfr. c. 128) a perjudicados concretos, personas físicas o jurídicas, incluso aunque el reo resulte absuelto en el aspecto penal (cfr. cc. 1729-1731, donde se regula la acción judicial para el resarcimiento de daños, ejercible en el mismo proceso penal).

- Lo que interesa señalar ahora, a este respecto, es que el c. $1718 \$ 4$ permite al Ordinario (no al juez) que, tras la investigación previa y antes de dar el decreto por el que decide si proceder o no y por qué vía (vide 6.6), considere si conviene pedir el consentimiento de las partes para que, bien él mismo, o bien el investigador que ha actuado, resuelvan de manera equitativa la cuestión de los daños, de modo que se eviten juicios innecesarios. En estos casos conviene tener presente:

- Que no se trata de un proceso judicial, en el que el juez o el tribunal, aplicando las disposiciones del derecho, dictaría una sentencia que impusiera a las partes la resolución en virtud de su potestad de juzgar. 
- Que, tal como prevé el derecho esta posibilidad, no se trata tampoco de una decisión administrativa, impuesta en virtud de la potestad ejecutiva.

- Se trata de una intervención de la autoridad para resolver la cuestión equitativamente, contando con el consentimiento de las partes.

- El consentimiento de las partes es, por tanto, necesario: ante todo, para autorizar que el Ordinario o el investigador intervengan conforme al c. $1718 \$ 4$; y también para dar vigor a la solución a la que se llegue: las partes deben alcanzar y hacer constar documentalmente un compromiso (en la línea de lo dispuesto por los cc. 17131716) de atenerse en ese aspecto a la decisión alcanzada, pues de lo contrario siempre podrían ejercer después la acción ordinaria de resarcimiento (cc. 1729-1731), haciendo inútil el intento de solución extrajudicial.

- Que el Ordinario, en virtud del c. $1718 \$ 4$ puede (y debe) proponer a las partes este tipo de actuación siempre que considere que es conveniente, con criterios análogos a los que apunta el c. 1446.

- Que se debe procurar que la resolución extrajudicial de la cuestión de daños se haga constar en un documento al que el derecho civil del lugar reconozca validez (cfr. c. $1718 \$ 4$ ): un acta firmada por las partes; un acuerdo firmado por las partes; etc.

6.8. La investigación previa y los remedios penales. La investigación previa, como se ha dicho, puede concluir con la decisión de no comenzar las actuaciones para imponer una pena.

- A veces, como consecuencia de la investigación y con arreglo a derecho, el Ordinario puede decidir (siempre por decreto: cfr. c. $1342 \$ 1$ ) aplicar otras medidas pastorales: los remedios penales y penitencias, ya tratados (vide 3.3; Anexo, 4.2 y 4.3). Puede suceder, en efecto, que de la investigación resulte la inocencia del investigado, pero convenga reprenderle a causa de imprudencias, desórdenes o errores, no delictivos (al menos no todavía, o no claramente), en su comportamiento (cfr. c. $1339 \$ \$ 1-2)$.

- Es posible igualmente que de la investigación resulten indicios que no sean suficientes para incoar un proceso o un procedimiento administrativo, pero que agraven las sospechas de la comisión de un delito, aunque no se pueda probar (cfr. c. $1718 \$ 1$ ). 
- Y puede suceder también que surjan de la investigación elementos graves y suficientes, que permitirían incoar las actuaciones penales, pero que antes de dar el decreto de conclusión de la investigación (cfr. c. 1718), el Ordinario, atendiendo a lo dispuesto por el c. 1341, decida comprobar si la corrección fraterna evangélica, o una advertencia de otro tipo, o un remedio penal propiamente dicho (reprensión o amonestación formales) son suficientes para que el sujeto rectifique, siempre que no haya escándalo u otras repercusiones. En este caso, los medios que se hayan puesto -y su resultado- constarán también en el expediente de la investigación previa y en la motivación del decreto en que se decide incoar o no el proceso o el procedimiento penal.

- En algunos casos, según su prudencia, el Ordinario puede añadir una penitencia a la reprensión o amonestación formales (c. $1340 \$ 3$ ).

- Cabe, finalmente, que el tipo de delito en cuestión esté penado con una censura. En ese caso la amonestación previa, como se ha indicado (vide 3.2.1), es requisito necesario para la válida imposición de la censura (c. $1347 \$ 1$ ). También se requiere la amonestación previa para poder aplicar algunas penas expiatorias previstas para determinados delitos (cfr., p. e., c. $1371 \$ 1$, etc.).

6.9. Normas especiales para los casos de delitos reservados a la CDF. Cuando el posible delito del que se tiene noticia es uno de los delicta graviora reservados a la Congregación para la Doctrina de la Fe, el procedimiento se rige por lo dispuesto en las normas de SST, que son claras.

- Las normas procedimentales relativas concretamente al delito de abuso sexual de un menor de 18 años por parte de un clérigo fueron ulteriormente sintetizadas en la citada Circular de la CDF, de 3 de mayo de 2011, sobre las Líneas Guía de actuación para los Ordinarios en estos casos. La consulta directa de esos documentos proporcionará la mejor pauta de actuación.

- El encuadramiento de los pasos iniciales de los procedimientos sobre casos de abuso de menores en el esquema general de procedimiento explicado hasta ahora sería el siguiente:

- Sigue siendo necesaria la investigación previa, responsabilidad del Ordinario (SST, art. 16). Si el caso es llevado directamente a la CDF (p. e. por una denuncia), sin que se haya hecho la investigación, la 
propia Cong. puede realizar las actuaciones que corresponderían originalmente al Ordinario (SST, art. 17).

- La investigación se lleva a cabo como se ha expuesto en los apartados 6 a 6.5. La Circular de 2011 indica expresamente que «a no ser que haya graves razones en contra, ya desde la fase de la investigación previa, el clérigo acusado debe ser informado de las acusaciones, dándole la oportunidad de responder a ellas» (esto no es todavía la acusación formal, que tendría lugar, en su caso, después de concluir la investigación y comenzar el procedimiento: vide 7.4.2.1).

- La Circular ofrece, además, otras indicaciones importantes sobre esta fase de las actuaciones. Concretamente, en lo relativo a la colaboración con las autoridades civiles, puesto que estas conductas son delitos tanto civiles como canónicos, se dice que «es importante cooperar en el ámbito de las respectivas competencias. En particular, sin perjuicio del fuero interno o sacramental, siempre se siguen las prescripciones de las leyes civiles en lo referente a remitir los delitos a las legítimas autoridades». Por tanto, las Conferencias episcopales, en las Lineas Guía que elaboren para su ámbito, «deben tener en cuenta la legislación del Estado en el que la Conferencia Episcopal se encuentra, en particular en lo que se refiere a la eventual obligación de dar aviso a las autoridades civiles». Así pues, en estos casos -sin excluir otros en que el delito canónico también lo sea en la legislación del Estado-, el Ordinario deberá asegurarse de que conoce bien y sigue lo dispuesto por su Conferencia episcopal al respecto.

- El decreto de conclusión (6.6), igual que en los casos comunes, debe ante todo valorar la investigación realizada, que será el fundamento de la decisión que se adopte. Concretamente, deberá expresar una de estas alternativas:

1) Que de la investigación resulta que no hay fundamento para proceder penalmente. En ese caso, la decisión que debería contener el decreto es archivar las actuaciones (cfr. SST, art. 16; vide 6.6,4).

- La causa puede ser, p. e., que los elementos recogidos muestran que la noticia del posible delito es claramente falsa; o que tras una investigación apropiada, rigurosa y completa, no se haya encontrado ningún elemento que permita comprobar su veracidad. 
2) Que, por el contrario, resulta que hay fundamento para proceder (c. $\left.1718 \$ 1,1^{\circ}\right)$. En este caso la decisión del decreto será la de remitir lo actuado a la CDF.

- La diferencia respecto a los casos no reservados es que aquí el Ordinario no toma ya las decisiones de las que trata el c. 1718 $\$ 1,2^{\circ}-3^{\circ}$ (sobre si conviene proceder y por qué vía: vide $6.6,2-$ 3). Solo debe enviar la documentación necesaria (se puede obtener de la propia CDF un formulario para remitir el caso, que indica todo lo necesario), junto con el informe del Ordinario, y atenerse a las instrucciones que la Congregación le irá dando desde que acuse recibo.

\section{MOdO DE PROCEDER PARA LA IMPOSICIÓN O PARA LA DECLARACIÓN DE PENAS}

7.1. Aclaraciones preliminares. Cuando un fiel desarrolla una conducta que podría ser delictiva (vide 5), la primera cuestión necesaria es determinar de qué delito se trataría concretamente y qué ley o qué precepto penal la tipifica (vide 2.4).

- Esto debe estar claro ya en la investigación previa (vide 6): con toda precisión desde el principio, o al menos de un modo suficiente para que la decisión de proceder penalmente no sea temeraria, aunque haya que acabar de precisar la calificación de la conducta considerada delictiva en el curso del proceso judicial o procedimiento administrativo que se abra para imponer la pena. En todo caso, la acusación (cfr. c. 1720 $\$ 1,1^{\mathrm{o}}$; vide 7.4.2.1), si llega a hacerse, debe ser clara y concreta.

- Como ya se ha indicado, si la conducta del reo, aunque resulte gravemente desordenada o incluso dañina, no está tipificada como delito, no se le puede imponer legítimamente una pena (solo sería posible intervenir penalmente en el caso excepcional que se expone en 7.2).

- A este respecto, conviene recordar que tanto la ley penal como el precepto penal están sujetos a interpretación estricta (cfr. cc. 18 y 36), por lo cual la conducta que se analiza en cada caso debe cumplir estrictamente, no de modo aproximado o analógico, los requisitos especificados por la ley.

- Por otra parte, conviene advertir también que la ley penal no puede ser retroactiva (es decir, no puede incluir una excepción de las previstas en 
el último inciso del c. 9), por lo que solo afecta a las conductas que se producen después de su promulgación. En consecuencia, si una persona hiciera algo reprobable, pero que en ese momento no es delito, y a continuación se diera una ley que pasara a considerar esa conducta como delito y previera la correspondiente pena, dicha ley no afectaría a los hechos pasados. Se aplicaría, en cambio, la ley más favorable al reo (aunque sea posterior), según el principio recogido en el c. $1313 \$ 1$.

- Recuérdese, por último, que todos los delitos han de consistir en conductas externas (vide 2.2), y a veces no solo externas, sino además con incidencia efectiva en la comunidad (cfr., p. e., c. 1330).

7.2. El supuesto excepcional del c. 1399. El c. 1399 regula un supuesto excepcional, para evitar que, por defecto o dificultad de previsión del derecho al tipificar los delitos, la autoridad eclesiástica quede reducida a la impotencia en algún caso en que sea verdaderamente necesario actuar penalmente para proteger el bien de la Iglesia.

- Concretamente se establece que, si se produjera una violación de la ley divina o eclesiástica no tipificada en el CIC o en otra ley (universal o particular), el Ordinario (no lo dice explícitamente el canon, pero el juez no tendría potestad para esta actuación) solamente puede castigar con una pena justa cuando se dan simultáneamente estos requisitos:

- que haya habido infracción externa de una ley divina o canónica no penal;

- que esa infracción sea especialmente grave;

- que urja la necesidad de reparar el daño y el escándalo.

- El primer requisito presupone que el derecho canónico no tipifica como delito, ni pretende hacerlo, toda violación teóricamente concebible del derecho divino y, lógicamente, tampoco de la ley eclesiástica. Por eso es posible que alguna vez se dé una conducta que en el momento de promulgar la ley no se consideró necesario configurar como delito (por su poca frecuencia, por su escasa relevancia comunitaria, o por otros motivos).

- Con este presupuesto, el c. 1399 permite que se actúe a su amparo solamente en supuestos de especial gravedad. De otro modo, se produciría una quiebra injustificable de la seguridad jurídica en la comunidad eclesial. Al valorar si una infracción concreta justifica una actuación de este tipo, deben considerarse los criterios generales que 
justificarían una actuación penal ordinaria (vide 1), pero reforzados ulteriormente por el carácter completamente excepcional de esta posibilidad de actuación (que técnicamente cae bajo la regla de derecho «odiosa restringenda»).

- En tercer lugar, el canon exige que, además de tratarse realmente de una infracción especialmente grave, sea urgente prevenir (en su caso, interrumpir) o reparar escándalos o daños debidos a la conducta en cuestión.

- Debe tenerse en cuenta que, en estos casos excepcionales, lo que autoriza el canon 1399 no es que se imponga directamente una pena sin observar procedimiento alguno, sino actuar penalmente -con los elementos y garantías esenciales de toda actuación penal- en un supuesto no tipificado previamente como delito.

- En la práctica -salvo que se trate de una conducta consistente en un solo acto, ya realizado y no reiterable: p. e., por consunción del objetopodrá atenderse normalmente de modo adecuado a la urgencia de reparar el escándalo dando previamente un precepto penal (vide 2.4.2). Se trataría de mandar o prohibir expresamente al sujeto una conducta, fijándole un plazo (que puede ser tan breve como desde el momento de la notificación: p. e., «al recibir la comunicación de este precepto», o «al día siguiente») y estableciendo una pena (incluso latae sententiae) adecuada a la gravedad de la conducta, para el caso de incumplimiento.

- En efecto, el simple hecho de que la autoridad interviniera de ese modo (dando a su actuación la publicidad adecuada a la naturaleza de la infracción), podría ser normalmente suficiente como primera medida (no necesariamente única o última) para contrarrestar el escándalo.

7.3. La decisión de seguir el proceso judicial. En los casos normales, cuando la investigación realizada confirma la noticia del delito que llevó a comenzarla (vide 5.1), el Ordinario, a la vez que expresa su decisión de proceder, debe determinar, en el mismo decreto que concluye la investigación (vide 6.6), si se va a seguir el proceso judicial o el procedimiento administrativo para imponer la pena (no es una cuestión indiferente, ni puede darse por resuelta de manera implícita o tácitamente: vide 7.4).

- El proceso judicial al que se refiere el c. 1342 es el proceso penal regulado específicamente en los cc. 1717 ss. La misión del Ordinario en este caso es entregar las actas de lo actuado (desde la noticia del delito 
hasta el decreto de conclusión de la investigación previa) al promotor de justicia, para que este ejerza su función ante el tribunal, preparando y presentando el escrito de acusación que dará comienzo al proceso (cfr. cc. 1721 ss.). A partir de ese momento termina la actuación administrativa del Ordinario y comienza la actuación judicial autónoma del tribunal.

7.4. La decisión de seguir la vía administrativa. Respecto al procedimiento administrativo para la imposición de penas, conviene indicar que el derecho canónico:

- Prevé que la ley pueda prohibir que se use este procedimiento en algunos casos (cfr. c. $1718 \$ 1,3^{\circ}$ ).

- Requiere, para optar legítimamente por seguirlo, que una justa causa se oponga (no es necesario que la impida de manera absoluta) a la opción del proceso judicial (cfr. c. $1342 \$ 1$ ). Pueden ser causa justa, p. e., la falta de jueces o de tribunal, así como otras circunstancias que incidan claramente sobre el aspecto procedimental de la actuación penal y no puedan ser calificadas de «causa injusta».

- Propone que el Ordinario tome esta decisión después de hacer la consulta prevista por el c. $1718 \$ 3$, si lo juzga oportuno.

- Exige que el procedimiento penal administrativo respete estrictamente en todo caso (cfr. c. 18) las normas que lo regulan, especialmente en todo lo que afecte a la garantía del derecho de defensa y a la justicia de la decisión (cfr. cc. $221 \S 3 ; 1720$ ).

7.5. El procedimiento del c. 1720 y sus referencias implícitas. El c. 1720 regula el modo de proceder solamente en sus pasos esenciales. Dentro de estos límites, el Ordinario, atendiendo a las circunstancias y cuidando siempre de garantizar al acusado el derecho de defensa (cfr. c. 1720, $1^{\circ}$; cfr. análogamente c. $1620,7^{\circ}$ en relación con c. $1342 \$ 3$ ), puede determinar discrecionalmente las actuaciones concretas de que constará cada procedimiento y su sucesión, así como los plazos y términos.

- No obstante, es oportuno indicar que el CIC contiene normas mucho más precisas sobre el proceso penal (cfr. cc. 1721 ss.) y sobre los elementos y actuaciones fundamentales del proceso en general (cfr. c. 1728). Aunque esos cánones no obligan en estos supuestos en cuan- 
to normas de procedimiento (cfr. c. $1342 \$ 3$ : de lo contrario, no tendría sentido no hacer un proceso judicial), sí que constituyen el punto de referencia implícito para obtener criterios sobre el modo de proceder que permitan actuar con acierto en los diversos aspectos que el c. 1720 no regula detalladamente (cfr. c. $19^{1}$ ).

7.6. Desarrollo posible de los pasos del procedimiento. A continuación se explica un posible desarrollo del procedimiento administrativo para la imposición de penas previsto por el c. 1720, con las principales referencias normativas que puede ser útil tener presentes para aplicarlo adecuadamente, ya que cada uno de los pasos establecidos puede incluir diversas actuaciones.

7.6.1. Comunicación de la acusación al reo. Cuando el Ordinario, en el decreto que concluye la investigación previa (cfr. c. 1718), decide legítimamente proceder por vía extrajudicial, el c. $1720 \$ 1,1^{\circ}$ dispone que debe, ante todo, comunicar al reo las acusaciones y las pruebas y darle oportunidad de que se defienda.

- Esto puede hacerse al notificar al reo el decreto (cfr. c. 54), pero teniendo en cuenta que, por ser una cuestión penal, casi siempre, deberá notificarse conforme al c. 55. En efecto, la naturaleza del asunto aconsejará que normalmente el Ordinario no se limite a comunicarlo por escrito, para guardar la adecuada reserva.

- Hay que tener en cuenta, además que redactar acabadamente una acusación formal con la enumeración completa de las pruebas puede ser todavía prematuro, porque el conocimiento de los hechos que se tiene en ese estadio del procedimiento, aunque sea suficiente para proceder, podría no superar de momento la categoría de indicio razonable; o presentar lagunas o errores en algunos aspectos. Por otra parte, entregarlo por escrito al reo podría resultar perjudicial para las actuaciones por otros motivos, poner en riesgo la fama de otras personas, etc.

${ }^{1}$ El c. 19 prohíbe aplicar la analogía en las causas penales, pero propiamente en lo relativo a los aspectos sustantivos del caso (p. e., considerar incluidas en un tipo delictivo ciertas conductas que la autoridad puede considerar semejantes a la tipificada, pero que no se mencionan expresamente en la ley, etc.), no en los aspectos de procedimiento que facilitan proceder correctamente y favorecen las garantías del reo (no si le perjudican o restringen sus derechos, ya que en ese caso se aplicaría el principio recogido en el c. 18). 
- En definitiva, la fase inicial del procedimiento puede incluir diversos actos, dependiendo de las circunstancias:

- Citación o convocatoria del reo. Puede hacerse por escrito, sin necesidad de especificar con detalle el asunto; o incluso oralmente, si se trata solo de solicitar su presencia. En todo caso, al convocarle se debe fijar claramente día ${ }^{2}$, hora y lugar para que el reo comparezca ante el Ordinario. Los cc. 1507-1512 podrían orientar sobre algunos aspectos de esta citación.

- Nombramiento de abogado. En cuestión de esta gravedad y que entraña cierta complejidad técnica, resulta conveniente en principio que el acusado cuente con la ayuda de un abogado, para evitar que resulte perjudicado el derecho de defensa (cfr. c. $212 \$ 3$ ). Según las circunstancias, el Ordinario, al citar al reo, puede indicarle la oportunidad de que designe un abogado que le acompañe ya en la comparecencia en la que se le comunicará la acusación. También podría proponerle durante esa comparecencia, una vez le haya comunicado la acusación, que nombre abogado ${ }^{3}$. Y en los casos en que se vea oportuno hacer la notificación solo por escrito, sin comparecencia, será oportuno incluir esa advertencia en el texto. Pueden orientar sobre esta materia los cc. 1723 y 1481-1490.

- Comparecencia para la comunicación. Deben estar presentes el Ordinario, el reo y al menos un notario o dos testigos (que puede convenir que sean las mismas dos personas que asesoran al Ordinario en el procedimiento: cfr. cc. $\left.1718 \$ 3 ; 1720,2^{\circ}\right)^{4}$. Ante todo, debe notificarse $^{5}$ al reo el decreto de conclusión de la investigación previa y apertura del procedimiento penal (cfr. c. $1718 \$ \$ 1-2$ ), si aún no se ha notificado (como se supone en estas páginas, para favorecer la ex-

${ }^{2}$ Bastaría dejar el intervalo de tiempo mínimo que se considere necesario, según las circunstancias: desde un par de horas después de una llamada telefónica, hasta unos días, etc. En su caso, la convocatoria oral se debe hacer constar en un acta, si hay testigo, o en un brevísimo documento firmado por el Ordinario (entre otras cosas, para el supuesto de incomparecencia).

3 En ese caso convendrá que, al comunicarle la acusación, se advierta al reo que, si lo desea, puede abstenerse de hacer ninguna declaración hasta que disponga de abogado.

${ }^{4}$ Cfr. c. 55. Se debe levantar acta de la notificación, por lo que si no está presente el notario, alguno de los presentes deberá realizar esa función.

5 Esto se puede hacer, bien dando lectura al texto, o bien entregándoselo al reo, para que lo lea en presencia de los participantes en el acto, o para que se lo lleve si nada aconseja lo contrario (cfr. cc. 55-56). 
plicación). Puesto que, generalmente, tanto la acusación como las razones y pruebas en que se basa la decisión de iniciar el procedimiento penal constarán en ese decreto solo sumariamente (cfr. c. 51), se podrá completar oralmente o por escrito la información, en la medida en que el reo lo necesite para garantizar que se le da posibilidad de defenderse adecuadamente de todas las imputaciones (cfr. c. $1720,1^{\circ}$ ).

- Posible incomparecencia del reo. Si el reo no compareciera cuando ha sido debidamente citado (cfr. c. $1720,1^{\circ}$ ), el Ordinario, después de hacer las necesarias comprobaciones (cfr. c. 1592), si considera que sería superfluo reiterar la convocatoria, debe hacer constar el resultado de ese intento infructuoso de notificación. Para ello puede pedir al notario que levante acta de la incomparecencia y de las comprobaciones y diligencias realizados; y dar un decreto para declarar ausente al reo en el procedimiento (cfr. c. $1724 \$ 2$ ). Después, puede continuar el procedimiento hasta el decreto final (cfr. c. $1720 \$ 2$ ). No obstante, si el reo comparece posteriormente, con el procedimiento todavía en marcha, y desea ejercer el derecho de defensa, el Ordinario lo admitirá, procurando evitar las maniobras puramente dilatorias. Puede servir de orientación a este respecto el c. 1592.

- Medidas cautelares. El Ordinario (cfr. c. $1342 \$ 3$ ), si lo considera necesario para cualquiera de los fines previstos por el c. 1722, puede tomar las medidas cautelares allí previstas, ya sin las limitaciones que se han señalado para la adopción de medidas cautelares provisionales durante la investigación previa (vide 6.2). Estas medidas pueden constar en el decreto de conclusión de la investigación (c. 1718), o en otro decreto separado (que se puede notificar al reo en ese momento o en otro, conforme a los cc. 54-56). También podrían comunicarse oralmente al reo en la misma comparecencia, de modo que se recojan en el acta.

- Fijación de la siguiente comparecencia. Una vez comunicados al reo todos los aspectos necesarios o convenientes, el Ordinario le dará un plazo (ordinariamente breve: p. e., de diez días útiles, o del tiempo que se considere razonable en las circunstancias del caso) para preparar adecuadamente su defensa y presentar las pruebas que considere oportunas (cfr. c. $1720,1^{\circ}$ ). El acto de comunicación oral concluirá con la firma de las actas por el reo (cfr. c. 56), el Ordinario y 
el notario o los testigos; y con la fijación de la fecha y hora de la siguiente comparecencia.

- Presentación de alegaciones y pruebas. El objetivo de esta comparecencia es la presentación de pruebas y alegaciones, escritas u orales, por parte del reo y también la práctica de las pruebas de la acusación que no se hayan podido practicar antes, p. e. el interrogatorio del reo. Puede ser necesario o no que se fije alguna sesión más para completar la tarea, evitando siempre las demoras innecesarias. En todo caso, el Ordinario debe asegurarse de que se cumplan las disposiciones de los cc. 1725 y $1728 \$ 2$. Pueden servir de orientación para la presentación, admisión y práctica de la prueba los cc. 1526-1586.

7.6.2. Valoración de las pruebas y alegaciones. El c. $1720,2^{\circ}$ describe la siguiente fase del procedimiento diciendo que, una vez terminadas las comparecencias y actuaciones oportunas, el Ordinario debe valorar cuidadosamente con dos asesores las pruebas y alegaciones presentadas en el procedimiento.

- Si nada lo impide, los asesores serán los dos jueces o expertos por otro título en derecho canónico mencionados en el c. $1718 \$ 3$. Para la valoración de las pruebas pueden ser orientadores los criterios que el CIC establece sobre la prueba en los procesos judiciales (cc. 1526-1586).

- El objetivo de esta valoración (cfr. c. $1720,3^{\circ}$ ) es ver si es posible alcanzar certeza acerca del delito y de su imputabilidad (vide 2; cfr. cc. 1321, $1717 \$ 1)$. Se trata de la certeza moral exigida para los jueces por el c. 1608 , que el c. $1342 \$ 3$ exige también explícitamente para el Ordinario en el procedimiento penal ${ }^{6}$. De lo contrario (tanto si no se alcanza esa certeza moral, como si se prueba la inocencia del acusado: cfr. c. 1726), el Ordinario debe dictar decreto motivado de absolución (en su caso, teniendo en cuenta la posibilidad de usar los remedios penales y penitencias previstos por el derecho: vide 6.8; cfr. cc. 1339-1340).

- En cambio, si alcanza la certeza moral necesaria, el Ordinario debe dar el decreto penal, en la última fase del procedimiento administrativo.

\footnotetext{
${ }^{6}$ Puede servir de orientación sobre el concepto el art. 247 \$ 2 de la Instrucción Dignitas connubii, aunque se refiere directamente al juez en los procesos matrimoniales: «Para la certeza moral necesaria conforme a derecho no basta el peso prevalente de las pruebas y de los indicios, sino que se requiere también que se excluya cualquier prudente duda positiva de error, tanto en cuanto al derecho como en cuanto a los hechos, aunque no quede eliminada la mera posibilidad de lo contrario».
} 
7.6.3. Decreto penal. Si, una vez finalizadas las actuaciones, consta con certeza el delito y no se ha extinguido la acción criminal (cfr. c. 1362), el Ordinario debe dar el decreto de condena -decreto penal-, por el que, en principio, se impone al reo la pena (cfr. c. $1720,3^{\circ}$ ).

- En cuanto al contenido de ese decreto, el CIC reitera específicamente (además de la norma general del c. $1342 \$ 3$ ) que el Ordinario puede ejercer las mismas facultades que usaría en el proceso el juez para decidir acerca de diversos aspectos de la aplicación de la pena, con arreglo a los cc. 1342-1350 (vide 8).

- En cuanto a la forma, en todo lo no regulado específicamente se aplican las normas generales sobre los decretos singulares (cc. 3558). Concretamente, la exigencia del c. 51 se completa aquí con la especificación de que, al exponer los motivos, este decreto debe expresar, «al menos brevemente, las razones de derecho y de hecho». Es decir, debe redactarse con un esquema lógico semejante al de una sentencia judicial (cfr. cc. 1608 ss.). Pueden servir de orientación, con las debidas adaptaciones, especialmente los cc. 1608, 1611 y 1612 .

- El decreto debe indicar los medios de impugnación de los que puede servirse el reo (cfr., para las sentencias, c. 1614). Concretamente, debe mencionar la posibilidad del recurso jerárquico y su plazo (cfr. cc. 1732-1739). Puesto que no se trata de uno de los supuestos previstos por el c. $1734 \$ 2$ (salvo cuando haya dado el decreto un Ordinario dependiente del Obispo), habrá que expresar también en el decreto la necesidad de hacer previamente la petición de revocación o enmienda que indica el c. $1734 \$ 1$. Tanto esa petición como el posterior recurso, suspenderían la pena conforme al c. 1353 mientras se resuelven.

- El decreto se debe notificar al reo conforme a los cc. 55-56.

\section{Normas y CRITERIOS SOBRE LA FIJACIÓN DE LA PENA}

8.1. Criterios generales. La imposición de las penas ferendae sententiae no es un simple automatismo, fruto de limitarse a aplicar mecánicamente una tabla predeterminada a priori por el Legislador. Por el contrario, las normas penales canónicas prevén un amplio margen prudencial, de discrecionalidad -siempre dentro del marco de la ley-, a la hora de aplicar las penas. 
- Decidir qué pena imponer en cada caso es una tarea que se deja, en buena medida, en manos del Ordinario (del juez, en el caso del proceso penal), para que su decisión pueda adaptarse lo mejor posible a las circunstancias concretas del caso, siempre sin desvirtuar el carácter propio de la actuación penal y asegurando que las decisiones que adopta en ejercicio de las facultades que el derecho le confiere en esta materia son aptas, en el caso, para conseguir los fines propios de la pena en el derecho canónico (cfr. c. 1341).

- Al elegir la pena que se va a imponer, es preciso comprobar ante todo de qué tipo es la pena prevista por la norma aplicable al caso: facultativa, preceptiva, determinada o indeterminada (vide 3.1.2), ya que de eso depende en parte el margen de discrecionalidad que el derecho concede al Ordinario en cada caso ${ }^{7}$, como se expondrá en seguida.

- Siempre se deben valorar específicamente, además, las circunstancias del caso: especialmente, el número de delitos cometidos; la reincidencia; la posible cooperación de otras personas en la actividad delictiva; las circunstancias eximentes, agravantes y atenuantes; el daño concreto causado a las víctimas directas, si las hay, y a la comunidad de fieles; el escándalo, que es un aspecto específico y cualificado de ese daño; las disposiciones personales del reo y de sus posibles cooperadores; etc.

- Según el c. 1348, cuando, de acuerdo con el derecho, el Ordinario decide no imponer ninguna pena en atención a las circunstancias (vide 8.3-8.4), puede, en todo caso, atender a las necesidades del bien común $\mathrm{y}$ a la utilidad del propio reo mediante remedios penales y penitencias (vide 3.3), y también por otros medios de solicitud pastoral (exhortaciones, advertencias, consejos, preceptos, etc.).

8.2. El número de delitos y de delincuentes. Entre las circunstancias que deben valorarse, como se ha indicado, el derecho atribuye relevancia directa al número de los delitos que se han cometido. Ordinariamente, en los casos de

\footnotetext{
${ }^{7}$ Con frecuencia -aunque no necesariamente-, el precepto penal lo emitirá el mismo Ordinario que deberá intervenir en caso de incumplimiento, de modo que puede tener en cuenta las circunstancias más relevantes del caso al establecerlo. No obstante, en su caso, en el procedimiento para aplicar la pena puede volver a valorar esos y otros extremos que considere oportunos para agravar, atenuar, sustituir o no imponer la pena, según vea más adecuado. Cuando, en cambio, el Ordinario impone una pena establecida por un precepto de otro Ordinario, será prudente que se atenga a las normas que rigen para la aplicación de la ley penal, que se tratarán en seguida.
} 
pluralidad de delitos ${ }^{8}$ (cfr. c. 1346), se aplicará el principio de que se deben imponer tantas penas como delitos se ban cometido, moderando equitativamente el resultado si el Ordinario juzga prudentemente que la aplicación estricta del principio general produciría una acumulación excesiva de penas.

- Este principio es aplicable cuando pueden distinguirse con claridad, numéricamente o en cuanto al tipo delictivo, varios delitos. Cuando se trata de actos reiterados, pero que pueden ser integrados en una misma conducta delictiva continuada o de tracto sucesivo, normalmente será más adecuado -y menos complejo- imponer una sola pena (la prevista para el delito de que se trate), pero graduando su gravedad en consideración de factores como la duración de la conducta delictiva, la frecuencia de la reiteración de actos, etc.

- En cuanto a la posible aplicación de penas a las personas que han cooperado de distintas formas en la comisión del delito (vide 2.3.7), ha de aplicarse fundamentalmente el c. 1329. Lógicamente, el establecimiento cierto del grado y tipo de cooperación de otras personas en el delito y la aplicación de penas, en su caso, debe hacerse siguiendo el mismo modo de proceder previsto (vide 6-8) para el autor principal del delito (citándolos, o bien al concluir la investigación previa si entonces ya hay elementos para ello, o bien durante el procedimiento ya en marcha si los elementos que sugieren su implicación en el delito resultan de las actuaciones posteriores) y respetando siempre el derecho de defensa.

8.3. Valoración de las circunstancias eximentes, atenuantes y agravantes. Las circunstancias que pueden modificar la imputabilidad (vide 2.3.3), eliminándola, atenuándola o agravándola, generalmente deberán valorarse en este momento del procedimiento, ya que aquí es precisamente donde ejercen su influencia sobre el contenido del decreto que concluye el procedimiento (cfr. c. $\left.1720,3^{\circ}\right)$.

- Los criterios fundamentales de valoración son los que indica el derecho cuando determina la influencia de cada una de esas circunstancias, incluyéndolas en uno u otro grupo. Además -aparte de la eficacia directa

\footnotetext{
${ }^{8}$ No debe confundirse este supuesto (la reiteración o pluralidad de los delitos cometidos antes de que la autoridad intervenga) con la reincidencia, que se da después de haber sido castigado por un delito (aunque la pena se suspenda o se decida legítimamente no aplicarla, como se explica más abajo).
} 
que puedan tener por sí mismas como circunstancias modificativas de la imputabilidad-, las normas canónicas las consideran a veces como elementos que la autoridad puede tener en cuenta al elegir la pena.

- Así, p. e., si el sujeto hubiera actuado con la libertad afectada por alguna de las circunstancias indicadas en el c. 1345, esta norma concede con carácter general al Ordinario la facultad de dejar de imponer cualquier tipo de pena prevista por el derecho, si piensa que por otro medio puede proveer mejor a la enmienda del reo. La condición es que en todo caso asegure la reparación de la justicia y del escándalo. Naturalmente, esta condición exige que la facultad otorgada se ejerza con una atenta consideración de las circunstancias y de la repercusión eclesial del caso.

8.3.1. Eximentes. Según el c. 1323, no queda sujeto a ninguna pena (en este caso, porque no se le puede imponer legítimamente, no porque el Ordinario decida no imponerla) quien al cometer la infracción tipificada:

- No había cumplido (aunque los hubiera incoado) los 16 años de edad.

- Ignoraba sin culpa (cfr. c. 1325) que estaba violando una ley o un precepto (no ignoraba necesariamente la existencia de la ley o el precepto, sino el hecho de que su conducta los violaba). A esta ignorancia se equiparan el error y la inadvertencia.

- Actuó por (no solo con) violencia física a la que no pudo resistir.

- Fue víctima de caso fortuito que no pudo prever o que, si hubiera previsto, no habría podido evitar (p. e., si una persona presionase sin querer un botón de su teléfono, al arrodillarse o sentarse, y grabara fortuitamente su confesión, no incurriría en el delito previsto por el c. 1386 \$ 3).

- Actuó coaccionado por miedo grave (incluso solo relativo: es decir, por una razón que podría no causar ese miedo a otras personas), o por necesidad o grave incomodo (en este último caso las leyes meramente eclesiásticas no obligan en conciencia), o juzgando erróneamente, pero sin culpa, que se daban esas circunstancias (todo ello, siempre que el acto realizado no sea intrínsecamente malo ni redunde en perjuicio de las almas: en caso contrario, esta circunstancia sería solo atenuante).

- Actuó en legítima defensa, propia o de otra persona, contra un injusto agresor, con una reacción proporcionada a la gravedad de la agresión que sufría (o que creía sufrir, erróneamente, pero sin culpa). Este su- 
puesto no se da solo en casos de violencia física sino, también, p. e., en supuestos en que se lesiona la fama (cfr. c. $1390 \$ 2$ ), etc.

- Carecía de uso de razón por una causa (estable o transitoria) no culpable, natural o no: p. e., por haber sido drogado o embriagado (si hubiera culpa o intencionalidad, se aplicarían los cc. $1324 \$ 1,2^{\circ}$ y 1325).

8.3.2. Atenuantes. El delincuente, conforme al c. 1324, no queda eximido de la pena establecida, pero el Ordinario debe mitigarla, o imponer en su lugar una penitencia, en los casos indicados en el canon. Y lo mismo puede hacer si se dan otras circunstancias semejantes que no se mencionen en la ley, pero que a su juicio disminuyen la gravedad del delito.

- La intensidad de la eficacia atenuante de cada una de las circunstancias apreciadas debe graduarla prudencialmente el Ordinario.

- Y se debe tener presente (cfr. c. $1324 \$ 3$ ) que cuando la pena por un delito (p. e., de aborto) es latae sententiae (vide 3.1.1), basta que se dé alguna de las atenuantes mencionadas en el canon (no hace falta que sea una eximente) para que el reo no incurra en ella.

- Concretamente, el c. 1324 aprecia una atenuante siempre que:

- El delito fue cometido por alguien que tiene (establemente) un uso de razón imperfecto (p. e., por causas psiquiátricas, etc.).

- El delito fue cometido con carencia transitoria y culpable de uso de razón, como en la embriaguez u otras perturbaciones de la mente similares (drogas, etc.), siempre que no hayan sido buscadas de intento precisamente para delinquir o para excusarse (en ese caso, sería una agravante).

- El delincuente actuó llevado por un arrebato de pasión, no buscado de propósito para delinquir (en caso contrario, sería una agravante).

- El reo tenía más de dieciséis años, pero menos de dieciocho cumplidos (es decir, era aún menor de edad).

- El delincuente se encontraba (o, debido a un error culpable, creía encontrarse) en la situación descrita en la eximente de miedo grave, necesidad o grave incomodo, pero en este caso hizo algo intrínsecamente malo o que redundaba en daño de las almas.

- El delincuente actuó como en la eximente de legítima defensa, pero desproporcionadamente (p. e., con violencia física contra una ofen- 
sa verbal), o creyendo culpablemente (p. e., porque reaccionó sin preguntar, aunque había tiempo, etc.) que se estaba produciendo una agresión que en realidad no existía.

- El delincuente actuó contra alguien que le provocaba grave e injustamente (de modo apto para producir una reacción violenta o de venganza que acabó en delito).

- El delincuente (que no necesariamente ignoraba que su conducta violaba la ley o el precepto, como en el caso de la eximente) ignoraba sin culpa (cfr. c. 1325) que el incumplimiento de la ley (divina o eclesiástica) o del precepto llevaba aparejada una pena.

- El delincuente actuó con imputabilidad no plena, aunque todavía grave (vide 2.3).

8.3.3. Agravantes. El c. $1326 \$ 1$ establece que se debe agravar la pena establecida por la ley o el precepto (p. e., aumentando su duración o la extensión de sus efectos posibles: número o tipo de actividades que se prohíben, etc.; no eligiendo la posibilidad más leve que permitiría la ley, etc.), cuando concurre alguna de las circunstancias que indica.

- Dispone además (\$2) que, cuando se da alguna agravante, si estaba prevista una pena latae sententiae para el delito, se le puede añadir una penitencia o incluso otra pena ferendae sententiae, siguiendo el procedimiento previsto (vide 7): en su caso, el decreto penal con el que concluya el procedimiento, primero declarará la pena latae sententiae (vide 3.2.1) y después impondrá la otra pena que se añada.

- Las circunstancias agravantes previstas por el CIC son las siguientes:

- Después de que le haya sido impuesta o declarada la pena por un delito, el delincuente sigue delinquiendo, de un modo que permite concluir que continúa su pertinacia en la mala voluntad.

- El delincuente está constituido en alguna dignidad eclesiástica (p. e., es canónigo, prelado de honor, etc.), aunque no sea un oficio de gobierno.

- El delincuente abusó de su oficio (cfr. c. $145 \$ 1$ ) precisamente para cometer el delito (p. e., aprovechando el acceso que tenía a unos fondos, la firma autorizada, la posibilidad de trato que le brindaba, etc.).

- Se trata de un delito culposo (vide 2.3.2) y el delincuente lo previó (no como mera posibilidad teórica y abstracta, sino como posibilidad 
real o cercana en sus circunstancias), pero aun así no adoptó las cautelas que cualquier persona con una diligencia normal hubiera adoptado para evitar ese riesgo.

- El delincuente actuó por embriaguez o por otras perturbaciones mentales similares, pero provocadas de modo voluntario, precisamente para cometer el delito (c. 1325).

- El delincuente actuó en un arrebato pasional, pero fomentado de modo voluntario precisamente para cometer el delito (c. 1325).

8.4. Ejercicio de la discrecionalidad dentro del marco de la ley canónica. Como ha quedado indicado, el Ordinario, al aplicar la pena conforme a los cc. 13421350 (cfr. c. $1720 \$ 2$ ), goza de cierto margen de discrecionalidad para elegir, entre las diversas opciones que el derecho le permite, la más adecuada, como resultado de la valoración de las circunstancias concretas del caso.

- En los casos en que el derecho permite, atendiendo a las circunstancias, abstenerse de imponer una pena (al igual que cuando hay que absolver), el Ordinario deberá valorar la posibilidad de proveer conforme a las posibilidades previstas por el c. 1348 (advertencias, consejos, remedios penales, etc.).

8.4.1. Facultades del Ordinario cuando la pena es preceptiva. En principio, el Ordinario que aplica exactamente la pena preceptiva prevista por la ley (vide 3.1.2), actúa correctamente, pero puede también adoptar otras decisiones legítimas, tomando en consideración las circunstancias del caso. Según el c. 1344, aunque el derecho establezca con palabras preceptivas la obligación de imponer la pena, el Ordinario, actuando en conciencia y prudentemente (naturalmente, aunque no se diga expresamente en este canon, asegurando ante todo que si actúa de ese modo no incurrirá en negligencia respecto a los otros fines de la pena: cfr. c. 1341), puede ejercer las siguientes facultades:

8.4.1.1. Retrasar la imposición de la pena a un momento más oportuno, si prevé que un castigo precipitado del reo podría acarrear males mayores (p. e., porque el reo ha comenzado un proceso de rectificación, porque está siguiendo un tratamiento de rehabilitación, porque es un delito oculto y un castigo inmediato podría aumentar su malicia provocando escándalo o infamando a personas, etc.). En estos casos se retrasaría la imposición misma de la pena (no 
se decide no imponerla, ni se suspende simplemente su cumplimiento, lo cual requeriría haberla impuesto previamente).

- Por tanto el procedimiento concluye con un decreto penal (cfr. c. 1720 $\$ 2$ ) que: a) declara probado el delito y la imputabilidad, con la expresión de las razones de hecho y de derecho; b) expone la decisión de diferir la pena, expresando los motivos; c) fija, de manera precisa o indeterminada, el tiempo en que se volverá sobre el asunto para tomar la decisión definitiva (que deberá ser siempre explícita, también en caso de que se decida en el futuro no imponer la pena conforme al c. 1344, $2^{\circ}$, teniendo en cuenta entonces el c. 1348).

8.4.1.2. No imponer la pena, rebajarla, o sustituirla por una penitencia (cfr. c. 1340), con tal de que, o bien el reo se haya enmendado y haya reparado el escándalo, o bien (no es necesario que ambas circunstancias coincidan) ya haya sido castigado de manera suficiente, o se prevé que lo será (p. e., porque ya está detenido y a la espera de juicio) por el derecho del Estado (si se trata de un delito tipificado simultáneamente por el derecho canónico y por el estatal).

- En estos casos el decreto penal debe contener: a) la declaración de que el delito resulta probado e imputable, con la exposición de las razones de hecho y de derecho; b) la decisión adoptada sobre la pena en virtud de esta facultad, con la expresión de sus motivos; c) en su caso, la imposición de un remedio penal o penitencia (cfr. c. 1348).

\subsubsection{Imponer la pena, pero suspender condicionalmente su cumplimiento -a} no ser que urja la necesidad de reparar el escándalo- si se trata del primer delito de alguien que hasta entonces había llevado una vida sin tacha. La condición que el derecho mismo incluye siempre que se toma esta decisión es que, si ese reo vuelve a delinquir (no es necesario que se trate de reincidencia en mismo tipo de delito) en el tiempo indicado por el Ordinario, deberá cumplir la pena por los dos delitos, una vez quede probado el segundo, después del correspondiente procedimiento penal, a no ser que haya prescrito la acción criminal por el primero en el intervalo (cfr. c. 1362).

- En estos supuestos, el decreto debería contener: a) la declaración de que el delito resulta probado e imputable, con la exposición de las razones de hecho y de derecho; b) la decisión de suspender la pena en 
virtud de esta facultad, con la expresión de sus motivos; c) la condición de no delinquir en el periodo de tiempo que el Ordinario determine; d) si es el caso, la imposición de algún remedio penal o penitencia (cfr. cc. 1339-1340).

- Si el reo volviera a delinquir dentro del periodo indicado por el Ordinario, debería seguirse el procedimiento correspondiente (vide 6 y 7), partiendo de la investigación previa. El decreto con el que concluiría este procedimiento, si es condenatorio, debería contener, además de los necesario respecto al nuevo delito, la declaración, en su caso, de que no se ha extinguido la acción criminal (c. 1362) por el primer delito y por tanto cesa la suspensión de la pena que se impuso en el procedimiento por el primer delito, que deberá empezar a cumplirse del modo que se indique.

8.4.2. Facultades del Ordinario cuando la pena es facultativa. En los casos en que la pena prevista es facultativa (vide 3.1.2), el Ordinario puede decidir (además de alguna de las medidas explicadas en 8.4.1, que resultan aplicables a fortiori) imponer la pena o no, siempre actuando en conciencia y prudentemente (cfr. c. 1343. En efecto, que exista esta facultad no significa que se trate de opciones indiferentes: para ser legítimas, deben ser razonadas).

- El Ordinario no debería decidir dejar de imponer la pena sin comprobar antes que, con la opción que adopte, quedarán satisfechas en cualquier caso las exigencias de la justicia, de enmienda del reo y de reparación del escándalo (cfr. c. 1341).

- Por otra parte, la elección no es solo entre imponer la pena o no hacer nada: caben asimismo todas las opciones intermedias entre esos dos extremos. Concretamente, el Ordinario puede también optar en estos casos (cfr. c. 1343) por atemperar (suavizar o disminuir) la pena -el modo concreto dependerá de la pena de que se trate: disminuir el tiempo, limitar los efectos, etc.-, o por imponer en su lugar una penitencia (cfr. cc. 1348, 1340; vide 3.3.3).

8.4.3. Determinación de las penas indeterminadas al imponerlas. Siempre que la ley (no el precepto: cfr. c. $1319 \$ 1$ ) prevé que el juez es quien deberá determinar una pena indeterminada (cfr. c. $1315 \$ 2$; vide 3.1.2), el Ordinario tiene la misma facultad. Para hacerlo: 
- Ha de comprobar que el tipo delictivo en el que encaja la conducta que ha sido objeto del procedimiento prevé como castigo una pena indeterminada.

- Debe elegir (teniendo en cuenta sobre todo el elenco del c. 1336, pero sin excluir otras penas, remedios penales o penitencias) la pena que sea más adecuada para castigar el delito de que se trate (cfr. cc. 1343, 1349: p. e., en algunos casos puede ser oportuno prohibir al reo ciertos actos del orden sagrado o participar en las reuniones de determinado consejo; se le puede añadir la obligación de estudiar y presentar resúmenes de cierto libro; etc.).

- Tiene que concretar también la duración de la pena, teniendo en cuenta la gravedad objetiva del delito y las condiciones subjetivas del delincuente (p. e., no es lo mismo un caso que ha creado gran escándalo y un delincuente contumaz, que un caso oculto y un delincuente que, al darse cuenta de lo que ha hecho, se arrepiente sinceramente).

- A no ser que lo requiera absolutamente la gravedad del caso (cfr. c. 1349), en estos casos de pena indeterminada, el Ordinario no debe imponer una censura (vide 3.2), salvo que la pena que prevé la ley para el caso sea precisamente una censura indeterminada. $Y$ en ningún caso puede imponer penas perpetuas ni la expulsión del estado clerical (vide 3.2.3).

- Procurará, en todo caso, que la solución que elige sea proporcionada a la gravedad del daño y del escándalo causados, satisfaga las exigencias de la justicia, y pueda ser útil para la enmienda del reo y la reparación del escándalo (cfr. cc. 1341, 1349).

- Al ponderar las cuestiones anteriores, deberá tener en cuenta también las posibles circunstancias atenuantes o agravantes, que a veces tendrán una importancia determinante para la decisión.

- En caso de que el delincuente sea un clérigo, habrá de tener en cuenta el c. 1350, para graduar la sanción, si es el caso, en cuanto a sus repercusiones económicas.

\section{Breve bibliografía complementaria}

Para completar el estudio de algún aspecto, especialmente de los tipos delictivos y del procedimiento, en los casos concretos pueden ser útiles, entre otros, los siguientes recursos: 
Código de Derecho Canónico. Edición anotada, Eunsa, Pamplona ${ }^{8} 2015$.

Código de Derecho Canónico. Edición comentada, BAC, Madrid ${ }^{6} 2014$.

De Paolis, V. - Cito, D., Le sanzioni nella Chiesa. Commento al Codice di Diritto Canonico, Libro VI, Urbaniana University Press, Città del Vaticano ${ }^{2} 2001$. Marzoa, Á. - Miras, J. - Rodríguez-Ocaña, R. (eds.), Comentario Exegético al Código de Derecho Canónico, Eunsa, Pamplona ${ }^{32002 .}$

Pighin, B. F., Diritto Penale Canonico, Marcianum, Venezia 2014.

PAPALE, C., Formulario commentato del processo penale canonico, Urbaniana University Press, Città del Vaticano 2012. 


\section{ESQUEMA BÁSICO DE ALGUNOS DECRETOS PREVIOS AL PROCEDIMIENTO PENAL}

\section{DECRETO DE ARCHIVO, SIN INVESTIGACIÓN PREVIA, DE LA NOTICIA DE UN POSIBLE DELITO, POR CONSIDERARLA INVEROSÍMIL}

\section{[Título]}

N.N., Obispo de... [oficio del Ordinario, si no es el Obispo]

Decreto singular sobre investigación conforme al c. 1717 del C.I.C.

\section{[Protocolo: para mayor discreción, puede ser específico del archivo secreto]}

Prot. n. XX/XX

\section{[Exposición de motivos]}

I. Como Ordinario competente para la actuación prevista en el c. 1717, he recibido [en tal fecha] la denuncia [la carta, el testimonio, los indicios, etc.] recogida en el expediente de referencia, que atribuye al sacerdote diocesano N.N. [al fiel laico de esta diócesis N.N., a la religiosa residente en esta diócesis N.N., etc.] la conducta quizá delictiva consistente en [breve descripción de la conducta de que se trate].

II. Tras considerar el asunto [y después de haber consultado con...], estimo que la noticia del supuesto delito resulta inverosímil por las siguientes razones: [expresión sintética de los motivos que llevan a esa valoración].

III. En consecuencia, conforme a lo dispuesto en el $\$ 1$ del citado canon, que manda evitar la apertura de una investigación cuando parezca del todo superflua,

\section{[decisión]}

DECRETO que se archive conforme al c. 1719 toda la documentación de este expediente, incluyendo el presente decreto.

\section{[lugar, fecha y firmas]}


2. DeCreto DE ARChIVO, Sin INVESTIGACión PREVIA, DE LA NOTICIA DEL POSIBLE DELITO POR TENER CERTEZA DE SU FALSEDAD

\section{[Título]}

N.N., Obispo de... [oficio del Ordinario, si no es el Obispo]

Decreto singular sobre investigación conforme al c. 1717 del C.I.C.

\section{[Protocolo: para mayor discreción, puede ser específico del archivo secreto]}

Prot. n. XX/XX

\section{[Exposición de motivos]}

I. Como Ordinario competente para la actuación prevista en el c. 1717, he recibido [en tal fecha] la denuncia [la carta, el testimonio, los indicios, etc.] recogida en el expediente de referencia, que atribuye al sacerdote diocesano N.N. [al fiel laico de esta diócesis N.N., a la religiosa residente en esta diócesis N.N., etc.] la conducta quizá delictiva consistente en [breve descripción de la conducta de que se trate].

II. Tras considerar el asunto [y después de haber consultado con...], estimo que la noticia del supuesto delito es falsa por las siguientes razones: [expresión sintética de los motivos que llevan a esa valoración].

III. En consecuencia, conforme a lo dispuesto en el $\$ 1$ del citado canon, que manda evitar la apertura de una investigación cuando parezca del todo superflua,

\section{[decisión]}

DECRETO que se archive conforme al c. 1719 toda la documentación de este expediente, incluyendo el presente decreto. [Se puede añadir alguna disposición relativa, por ejemplo, al autor de la denuncia falsa, o a la proporcionada difusión del contenido del decreto, si la noticia falsa del delito se había divulgado en algún ámbito].

\section{[lugar, fecha y firmas]}




\section{DeCreto de apertura de la inVESTigación PREVIA Y, EN SU CASO, DESIGNACIÓN DEL INVESTIGADOR}

\section{[Título]}

N.N., Obispo de... [oficio del Ordinario, si no es el Obispo]

Decreto singular de apertura de investigación conforme al c. 1717 del C.I.C.

\section{[Protocolo: para mayor discreción, puede ser específico del archivo secreto]}

Prot. n. XX/XX

\section{[Exposición de motivos]}

Como Ordinario competente, he recibido [en tal fecha] la denuncia [la carta, el testimonio, los indicios, etc.] recogida en el expediente de referencia, que atribuye al sacerdote diocesano N.N. [al fiel laico de esta diócesis N.N., a la religiosa residente en esta diócesis N.N., etc.] la conducta quizá delictiva consistente en [breve descripción de la conducta de que se trate]. Tras considerar atentamente la verosimilitud de la noticia y las demás cuestiones pertinentes,

\section{[decisión]}

DECRETO que se abra una investigación conforme al c. 1717, acerca de los hechos, circunstancias y, en su caso, imputabilidad de la conducta investigada. La investigación se prolongará hasta que yo mismo considere posible tomar una decisión fundada, con arreglo al c. 1718.

Teniendo en cuenta las circunstancias del asunto, llevaré a cabo personalmente esta investigación, incorporando al expediente todos los documentos que recabe y las diligencias que realice.

[o: Teniendo en cuenta las circunstancias del asunto, designo a N.N. para que lleve a cabo esta investigación conforme al c. $1717 \$ 3$ (cfr. c. $1428 \$ 3$ ), bajo estricta reserva y manteniéndome permanentemente informado sobre su desarrollo].

[En su caso: Por las características de los posibles hechos delictivos y del investigado, he decidido que, mientras dure la investigación, (explicar las cautelas provisionales que haya decidido adoptar: vide 6.2)].

\section{[lugar, fecha y firmas]}




\section{DECRETO DE CONCLUSIÓN DE LA INVESTIGACIÓN PREVIA}

\section{[Título]}

N.N., Obispo de... [oficio del Ordinario, si no es el Obispo]

Decreto singular de conclusión de investigación conforme al c. 1718 del C.I.C.

\section{[Protocolo: deberá tener en cuenta el protocolo del decreto de apertura de la investigación]}

Prot. n. XX/XX

[4.1. Conclusión de la investigación y archivo de las actuaciones por inocencia del investigado]

\section{[Exposición de motivos]}

Durante la investigación abierta mediante mi decreto Prot. n. XX/XX, de fecha..., [en su caso: llevada a cabo, bajo mi autoridad, por N.N.], no han aparecido elementos que corroboren la noticia de posible delito [denuncia, etc.] que dio origen a estas actuaciones [o: se han conocido elementos que atestiguan la inocencia del investigado; o: se han conocido elementos que llevan a concluir que la supuesta conducta delictiva carece de fundamento; etc. En su caso, se puede hacer una breve descripción de las razones que llevan a esa conclusión]. En consecuencia [después de consultar, conforme al c. $1718 \$ 3$, mi decisión con N.N.],

\section{[decisión]}

DECRETO, con arreglo al c. $1718 \$ 1$, que quede concluida la investigación y se archiven las actuaciones conforme al c. 1719 [según las circunstancias del caso, puede ser oportuno mandar adicionalmente que se dé noticia de esta decisión, por ejemplo, a la persona denunciante; al propio investigado, si tenía conocimiento de la investigación iniciada; a quienes han sabido de la investigación en marcha, p. e., porque se les ha pedido información, etc. También según las circunstancias, se les puede imponer la obligación de secreto]. [También es posible emplear con el investigado algún remedio penal si, a pesar de su inocencia conviene reprenderle o amonestarle formalmente: vide 6.8].

\section{[lugar, fecha y firmas]}


[4.2. Conclusión de la investigación y archivo de las actuaciones con sospecha pero sin datos]

\section{[Exposición de motivos]}

I. Durante la investigación abierta mediante mi decreto Prot. n. XX/XX, de fecha..., [en su caso: llevada a cabo, bajo mi autoridad, por N.N.], no han aparecido elementos que corroboren la noticia de posible delito [denuncia, etc.] que dio origen a estas actuaciones, ni es previsible que pudieran ya aparecer si se prolongasen más tiempo.

II. Permanecen las sospechas sobre la conducta del investigado, pero no ha sido posible encontrar base alguna que permita intentar la prueba de algún hecho delictivo concreto en un procedimiento penal. En consecuencia [después de consultar, conforme al c. $1718 \$ 3$, mi decisión con N.N.],

\section{[decisión]}

DECRETO, con arreglo al c. $1718 \$ 1$, que quede concluida la investigación y se archiven las actuaciones conforme al c. 1719, sin emprender proceso o procedimiento penal por los hechos investigados. [No obstante, citaré cuanto antes al investigado para amonestarle formalmente, conforme al c. $1339 \$ 1]$.

\section{[lugar, fecha y firmas]}

[4.3. Conclusión de la investigación con la decisión de no proceder penalmente, aunque se podría]

\section{[Exposición de motivos]}

I. Durante la investigación abierta mediante mi decreto Prot. n. XX/XX, de fecha..., [en su caso: llevada a cabo, bajo mi autoridad, por N.N.], han aparecido elementos que corroboran la noticia de posible delito [denuncia, etc.] que dio origen a estas actuaciones y permitirían intentar la prueba de la conducta delictiva en un procedimiento penal.

II. No obstante, teniendo en cuenta [que no se trata de una conducta especialmente grave; que es la primera vez que el investigado incurre en ella; que el investigado, al ser amonestado, ha dado muestras de arrepentimiento; etc.], y atendiendo al c. 1341 (cfr. c. $1718 \$ 1,2^{\circ}$ ), estimo que en esta ocasión no conviene proceder penalmente, por poderse alcanzar [haberse alcanzado] por otros medios de solicitud pastoral los fines que la actuación penal procuraría. 
En consecuencia [después de consultar, conforme al c. $1718 \$ 3$, mi decisión con N.N.],

\section{[decisión]}

DECRETO, con arreglo al c. $1718 \$ 1$, que quede concluida la investigación y se archiven las actuaciones conforme al c. 1719, sin emprender proceso o procedimiento penal por los hechos investigados. [No obstante, citaré cuanto antes al investigado para amonestarle formalmente, conforme al c. $1339 \$ 1$; o: para imponerle, conforme al c. 1340 la penitencia consistente en...; o ambas cosas].

\section{[lugar, fecha y firmas]}

[4.4. Conclusión de la investigación con la decisión de proceder penalmente]

\section{[Exposición de motivos]}

I. Durante la investigación abierta mediante mi decreto Prot. n. XX/XX, de fecha..., [en su caso: llevada a cabo, bajo mi autoridad, por N.N.], han aparecido elementos que corroboran la noticia de posible delito [denuncia, etc.] que dio origen a estas actuaciones y permitirían intentar la prueba de la conducta delictiva en un procedimiento penal.

II. Atendiendo al c. 1341 (cfr. c. $1718 \$ 1,2^{\circ}$ ), estimo que en esta ocasión conviene proceder penalmente, por no poderse alcanzar [haberse podido alcanzar] por otros medios de solicitud pastoral [en su caso, relatar las correcciones o amonestaciones infructuosas, que constarán documentalmente en el expediente] los fines que la actuación penal pretende.

En consecuencia [después de consultar, conforme al c. $1718 \$ 3$, mi decisión con N.N.],

\section{[decisión]}

DECRETO, con arreglo al c. $1718 \$ 1$, que quede concluida la investigación y se inicie el procedimiento penal con la citación inmediata del investigado, conforme al c. $1720,1^{\circ}$ [o, en caso de que se decida proceder judicialmente: que quede concluida la investigación y se trasladen las actas al promotor de justicia para que proceda conforme al c. 1721]. Archívense con- 
forme al c. 1719 los documentos del expediente innecesarios para el procedimiento penal.

\section{[lugar, fecha y firmas]}

\section{DECRETO DE APERTURA INMEDIATA DEL PROCEDIMIENTO \\ ADMINISTRATIVO PENAL, SIN INVESTIGACIÓN PREVIA, QUE SE CONSIDERA \\ INNECESARIA PORQUE HAY YA ELEMENTOS SUFICIENTES PARA PROCEDER}

\section{[Título]}

N.N., Obispo de... [oficio del Ordinario, si no es el Obispo]

Decreto singular de apertura de procedimiento penal conforme al c. 1720 del C.I.C.

\section{[Protocolo: para mayor discreción, puede ser específico del archivo secreto]}

Prot. n. XX/XX

\section{[Exposición de motivos]}

I. Como Ordinario competente para la actuación prevista en el c. 1717, he recibido [en tal fecha] la denuncia [la carta, el testimonio, los indicios, etc.] recogida en el expediente de referencia, que atribuye al sacerdote diocesano N.N. [al fiel laico de esta diócesis N.N., a la religiosa residente en esta diócesis N.N., etc.] la conducta quizá delictiva consistente en [breve descripción de la conducta de que se trate].

II. Tras estudiar el asunto [y después de haber consultado con... (cfr. c. $1718 \$ 3)$ ], estimo que la noticia del supuesto delito resulta verosímil y que, en cuanto a los hechos, circunstancias e imputabilidad (cfr. c. $1717 \$ 1$ ), parece avalada por las razones y elementos de prueba que constan en el expediente [o: que a continuación se exponen] y que, según mi estimación, hacen innecesaria una ulterior investigación con el fin de averiguar si existe fundamento suficiente para iniciar la actuación oportuna (cfr. c. $1717 \$ 1$ ).

III. Teniendo en cuenta el c. 1341, considero sin embargo que en este caso conviene proceder penalmente (cfr. c. $1781 \$ 1,2^{\circ}$ ) [en su caso, se pueden enunciar sintéticamente las razones que muestran que otros medios de so- 
licitud pastoral no bastan] y que, por las circunstancias [por la urgencia del caso; por la gravedad del caso; etc.], es conveniente hacerlo por la vía extrajudicial (cfr. c. $1718 \$ 1,3^{\circ}$ ).

Por todo lo cual,

\section{[decisión]}

DECRETO que se inicie el procedimiento administrativo penal con la citación inmediata del reo para que comparezca, conforme al c. 1720, $1^{\circ}$; y que este decreto, junto con toda la documentación del expediente que no sea necesaria para el procedimiento penal, se archive conforme al c. 1719.

\section{[lugar, fecha y firmas]}




\section{INFORMACIÓN E INSTRUCCIONES PARA LOS AUTORES Y REVISORES}

1. La revista Ius Canonicum publica dos números por año, en junio y diciembre. El contenido del primer número del año queda definitivamente fijado el 30 de marzo, mientras que el segundo es cerrado el 30 de septiembre; sin perjuicio, naturalmente, de que la programación de la Revista alcance más allá del año en curso.

2. Los autores someterán sus artículos a través de la plataforma OJS (Open Journal Systems), adaptada para Ius Canonicum, a través del siguiente enlace: http://www. unav.edu/publicaciones/revistas/index.php/ius-canonicum/.

Durante todo el proceso de preparación del número de la revista, OJS será el cauce de comunicación entre el autor y el editor. Para resolver cualquier duda en relación con el procedimiento los autores pueden dirigirse a: mhergot@unav.es.

3. Las colaboraciones deberán ser textos inéditos y originales. El autor podrá usar libremente el texto cuando haya sido publicado, con la oportuna cita de Ius Canonicum como lugar original de publicación. La Revista juzgará la posibilidad de publicar en ocasiones la versión española de textos presentados en Congresos y aún no publicados; en tal caso se hará constar esta circunstancia en una nota previa a pie de página.

4. Las colaboraciones para las secciones de «estudios»y de «comentarios» no deberán superar las 15.000 palabras, incluidas las notas a pie de página. Constará el nombre y apellidos del autor, así como el cargo académico o profesional (solamente uno) y la dirección del correo electrónico. Además, se incluirá al final del artículo la relación completa de la bibliografía citada.

5. Los textos que sean destinados a la sección de «estudios» deberán contener un resumen de 150 palabras en español y en inglés. Igualmente, se incluirán en ambas lenguas, tres palabras clave (keywords).

6. Una vez recibido el original, la Revista informará al autor del comienzo del proceso anónimo de revisión. Éste consiste en la evaluación del texto por parte de dos revisores externos al Consejo Editorial de la Revista, que juzgan si su forma y contenido se ajustan a los criterios científicos vigentes en el derecho canónico y disciplinas afines. El Director de la Revista comunicará al autor el resultado del proceso revisor, indicando si el escrito ha sido aceptado o rechazado y, en su caso, las mejoras o modificaciones que se propongan. En el plazo habitual de 2 meses, y máximo de 4, el Consejo Editorial comunicará la aceptación o rechazo de un artículo, junto con las observaciones o sugerencias emitidas por los evaluadores. 
7. Sección de bibliografía. El Consejo Editorial escoge, de entre los libros recibidos en la secretaría de la revista, aquellos que serán objeto de comentario bibliográfico o de recensión. El Consejo Editorial, asimismo, designa, de entre los colaboradores fijos de la sección de bibliografía, a quien haya de encargarse de elaborar el comentario o la recensión. La extensión del comentario bibliográfico se fija en 4.000-6.000 palabras; de la recensión en 1.000-2.000 palabras.

\section{Responsabilidades éticas}

8. Es responsabilidad y deber de la redacción de la revista Ius Canonicum recordar a los autores estos extremos:

- La revista no acepta material previamente publicado. Los autores son responsables de obtener los oportunos permisos para reproducir parcialmente material (texto, tablas o figuras) de otras publicaciones y de citar su procedencia correctamente.

- Conflicto de intereses. La revista espera que los autores declaren cualquier posición o actividad que pueda suponer un conflicto de intereses en conexión con el artículo remitido.

- Autoría. En la lista de autores firmantes deben figurar únicamente aquellas personas que han contribuido intelectualmente al desarrollo del trabajo. En general, para figurar como autor se deben cumplir los siguientes requisitos:

1. Haber participado en la concepción y realización del trabajo que ha dado como resultado al artículo en cuestión.

2. Haber participado en la redacción del texto y en las posibles revisiones del mismo.

La Revista declina cualquier responsabilidad sobre posibles conflictos derivados de la autoría de los trabajos que se publican en la Revista.

- Los juicios y opiniones expresados en los artículos publicados en la Revista son del autor(es) y no necesariamente del Consejo Editorial.

\section{Modos de citar}

9. Libros: J. Hervada, Elementos de Derecho constitucional canónico, Eunsa, Pamplona ${ }^{3} 2014,288$ pp.

O. Condorelli, Unum corpus, diversa capita. Modelli di organizzazione e cura pastorale per una varietas ecclesiarum (secoli XI-XV), Il Cigno Galilei, Roma 2002, 243 pp.

Artículos de revista: A. MORENO GARCÍA, El servicio de indagación prejudicial: aspectos jurídico-pastorales, Ius Canonicum 56 (2016) 65-85.

J.-P. SCHOUPPE, La dimension juridique de la Parole et des sacrements ainsi que de la «communio», L'année canonique 42 (2000) 167-188. 
Participaciones en obras colectivas: H. PREE, Die Ausïbung der Leitungsvollmacbt, en J. LisTL - H. MÜLLER - H. SCHMITZ (eds.), Handbuch des katbolischen Kirchenrechts, Pustet, Regensburg 1983, 131-141.

Comentarios legislativos: C. GULLO, sub c. 1476, en Comentario exegético al Código de Derecho Canónico, V, Eunsa, Pamplona 32002, 1022-1024.

Voces de diccionario: R. PUZA, «Institutionensystem», en A. V. CAMPENHAUSEN - I. RIEDEL SpANGENBERGER - R. SEBOTT (eds.), Lexicon fuir Kirchen-und Staatskirchenrecht, II, Ferdinand Schöningh, Padeborn-München-Wien-Zürich 2002, 305-307.

D. Cenalmor, «Dimisorias [Letras]», en J. Otaduy - A. Viana - J. Sedano (eds.), Diccionario General de Derecho Canónico, III, Thomson Reuters Aranzadi, Cizur Menor (Navarra) 2013, 335-338 (en adelante, DGDC).

Obras ya citadas: E. Molano, Estructuras jerárquicas..., cit., 327-335.

En las citas deberá evitarse un número excesivo de abreviaturas, limitándose a las más conocidas (CIC, AAS, etc.).

Criterio para obras ya citadas: Primeras palabras del título... (puntos suspensivos), cit., 832 .

\section{Numeración de títulos y epígrafes}

10. Los títulos de los apartados y subapartados de los Estudios, Comentarios y Crónicas seguirán el siguiente orden y diseño:

1. El Objeto de LA EXCLUSióN

\subsection{Planteamiento}

1.1.1. Actos

11. Los epígrafes para los sumarios de los Comentarios y Crónicas seguirán el siguiente orden y diseño:

SuMARIO: 1. Curia romana. 1.1. Congregaciones. 1.1.1. Congregación para la Doctrina de la Fe (modificaciones al motu proprio «Sacramentorum sanctitatis tutela»).

\section{Revisores}

12. - Los artículos se someterán a doble revisión anónima por expertos ajenos al Consejo Editorial.

- Se garantiza la confidencialidad de los autores y de los revisores.

- Periódicamente se dará a conocer la lista de revisores de Ius Canonicum, sin indicación de los trabajos revisados. 


\section{IUS CANONICUM}

REVISTA SEMESTRAL FUNDADA EN 1961

EDITA: SERVICIO DE PUBLICACIONES DE LA UNIVERSIDAD DE NAVARRA

PAMPLONA / ESPAÑA

ISSN: 0021-325X

\section{ESTUDIOS SOBRE EL MOTU PROPRIO MITIS IUDEX (II)}

La fase preliminar del nuevo proceso de nulidad

Gerardo Núñez. Págs. 9-44

El artículo 14 de las Reglas de Procedimiento del M. P. Mitis Iudex.

Supuestos de hecho y causas de nulidad

Juan Ignacio Bañares. Págs. 45-81

Il servizio alla verità nel processo matrimoniale

Paolo Bianchi. Págs. 83-104

La dimensión jurídica del matrimonio canónico a la luz del magisterio reciente.

Observaciones a propósito de la reforma del proceso de nulidad realizado

por el Motu proprio Mitis Iudex

Montserrat Gas-Aixendri. Págs. 105-128

La indisolubilidad del matrimonio: su problemática comprensión actual

y la importancia de una fundamentación antropológico-jurídica

Carlos José Errázuriz. Págs. 129-150

\section{OTROS ESTUDIOS}

Dulcor Misericordiae. Justicia y misericordia en el ejercicio de la autoridad canónica.

II. El capítulo octavo de Amoris Laetitia

Javier Otaduy. Págs. 153-201

Los fieles miembros de ordinariatos para antiguos anglicanos y su incorporación a la diócesis José María Chiclana. Págs. 203-238

El abogado ante las causas matrimoniales canónicas. Ciertas cuestiones deontológicas José María Martí Sánchez. Págs. 239-276

Estudio canónico sobre la viudez consagrada

Christina Hip-Flores. Págs. 277-320

GUÍAS CANÓNICAS. Págs. 323-385

CRÓNICAS. Págs. 389-446

BIBLIOGRAFÍA. Págs. 449-485 